Primljen / Received: 31.5.2012. Ispravljen / Corrected: 30.3.2013.

Prihvaćen / Accepted: 1.4.2013. Dostupno online / Available online: 10.4.2013.

\section{A review of soil and reinforcement interaction testing in reinforced soil by pullout test}

Authors:

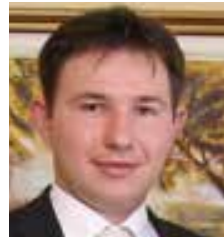

Krunoslav Minažek, PhD. CE University J.J. Strossmayer of Osijek Faculty of Civil Engineering krumin@gfos.hr

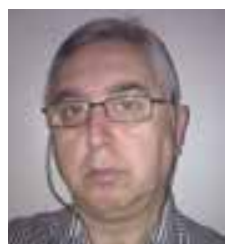

Prof. Mensur Mulabdić, PhD. CE University J.J. Strossmayer of Osijek Faculty of Civil Engineering mulabdic@gfos.hr

\section{Krunoslav Minažek, Mensur Mulabdić}

\section{A review of soil and reinforcement interaction testing in reinforced soil by pullout test}

A review of current knowledge on model studies of reinforced soil by pullout test is described in the paper. The pullout test, highly significant in soil-reinforcement characterisation, is described through a review of studies that have contributed to the characterisation of soil-grid interaction and development of testing techniques. The influence of test boundary conditions and other factors on pullout test results is described. The pullout testing apparatus developed at the Faculty of Civil Engineering in Osijek is presented.

Key words:

interaction, reinforced soil, geosynthetics, geogrids, model test, pullout test

Pregledni rad

Krunoslav Minažek, Mensur Mulabdić

Pregled ispitivanja interakcije tla i armature u armiranom tlu pokusom izvlačenja

U radu su opisana dosadašnja dostignuća o modelskim istraživanjima armiranog tla pokusom izvlačenja armature iz tla. Ispitivanje izvlačenjem, vrlo značajno za karakterizaciju interakcije tla i armature, opisano je kroz pregled istraživanja koja su pridonijela spoznajama o interakciji i razvoju tehnike ispitivanja. Opisan je utjecaj rubnih uvjeta i drugih faktora na rezultate ispitivanja u pokusu izvlačenja. Prikazan je veliki uređaj za izvlačenje razvijen na Gradevinskom fakultetu u Osijeku.

Ključne riječi:

interakcija, armirano tlo, geosintetici, geomreže, modelsko ispitivanje, pokus izvlačenja armature

Übersichtsarbeit

Krunoslav Minažek, Mensur Mulabdić

\section{Übersicht der Tests zur Boden-Bewehrung-Interaktion in bewehrten Böden} durch Pullout-Versuche

In dieser Arbeit werden vorhandene Kenntnisse bezüglich verschiedener Modellstudien an armierten Erdböden durch Ziehproben der Bewehrungen aus dem Boden beschrieben. Untersuchungen durch Pullout-Versuche, bedeutend für die Charakterisierung der Wechselwirkungen zwischen Boden und Bewehrung, sind durch eine Übersicht der Forschungen, die zu Einsichten in Bezug auf die Interaktion und die Entwicklung der Prüftechniken beigetragen haben, beschrieben. Der Einfluss von Randbedingungen und anderen Faktoren auf die Testresultate ist ebenfalls dargestellt. Ein Testgerät, das an der Fakultät für Bauwesen in Osijek entwickelt wurde, wird beschrieben. 


\section{Introduction}

Reinforced soil can be defined as composite of soil and geosynthetic reinforcement, usually geotextile or geogrid, sometimes polymer or metal strips or, less frequently, metal grids. Retaining walls, steep embankment slopes, unstable slope stabilization, improving and strengthening the roadbases can be performed by the soil reinforcement technique. Increasing use of geosynthetics rise questions about the interaction mechanisms between soil and geosynthetic as reinforcement, as well as the effectiveness of different types of geosynthetics for different conditions in soil. This stimulated the development of studies of the soil - reinforcement interaction mechanisms through development of theoretical and numerical models, model tests and tests on structures.

For each of possible mechanisms of internal collapse in the reinforced soil embankment (Figure 1) reinforcement interacts with soil in a different way. Depending on the collapse mechanism, different models for soil and reinforcement interaction testing were developed [1]. Shear in the plane of the soil and reinforcement contact in the $A$ zone can be tested by a test which is designed as a direct shear test. In the B zone, soil and reinforcement move laterally so that the in soil tensile test of reinforcement in soil would be the appropriate test for this mechanism. Direct shear tests with inclined reinforcement in relation to the shear plane present a simulation of the interaction mechanism that occurs in the $\mathrm{C}$ zone. Pullout testing reproduces the mechanism appearing in the $D$ zone where the reinforcement pullout from soil occurs.

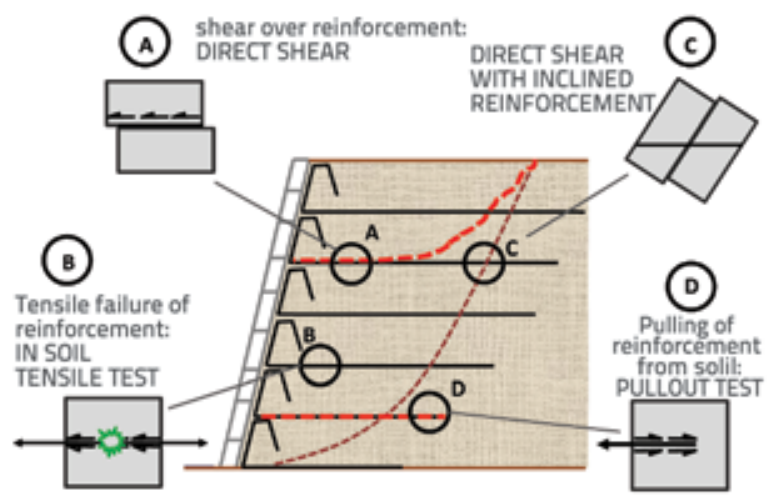

Figure 1. Cross-section of embankment /wall of reinforced soil with failure mechanisms and tests that correspond to a particular failure mechanism, [1]

Soil and reinforcement interaction tests that become prevailing in practice are model testing by pullout test and direct shear. They differ in the way of applying force and boundary conditions, which leads to a different distribution of stresses that develop in the reinforcement and soil and results in different failure mechanisms [2]. Pullout test has been developing over the past thirty years. It provides parameters that are needed to determine the length of the reinforcement anchoring, and it has proved as important in explaining the interaction mechanisms of different types of soil and reinforcement. Model test by reinforcement pullout from soil is important because it can be used to clarify the mechanisms of soil and reinforcement interaction, to establish criteria for selection of materials in the reinforced soil structures and to allow the application of test results in obtaining the specific parameters that can be used when designing the reinforced soil structures.

\section{Description of model reinforced pullout test}

In model test of the reinforcement pullout from soil the reinforcement (length $L$ and width $B$ ) is installed in a metal box of the pullout device between two soil layers. The force required for pullout and displacements occurring along the reinforcement length at pullout are determined. Figure 3 shows typical results of the pullout test. Development of displacements with increase of the pullout force is shown at four measuring points placed along the reinforcement sample (E1, E2, E3, E4, layout from Figure 2). At high values of normal stresses and/or large reinforcement length, the reinforcement failure due to exceeding its tensile strength (Figure $3 \mathrm{~b}$ ) can occur instead of pullout.

Pullout is conducted by a controlled increase in displacement or force with corresponding normal stress (up to $200 \mathrm{kPa}$ in the reinforcement plane, usually achieved by using air bags installed under the cover of the pullout device).

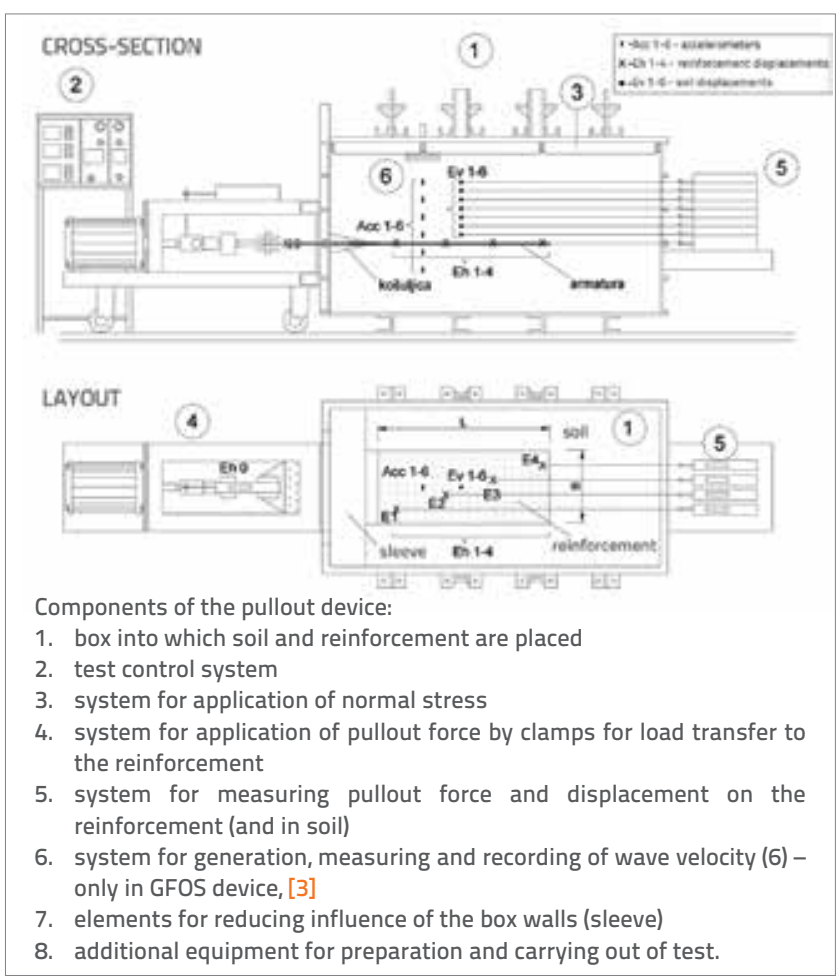

Figure 2. Cross-section and layout of large pullout device (GFOS pullout device [3]) 

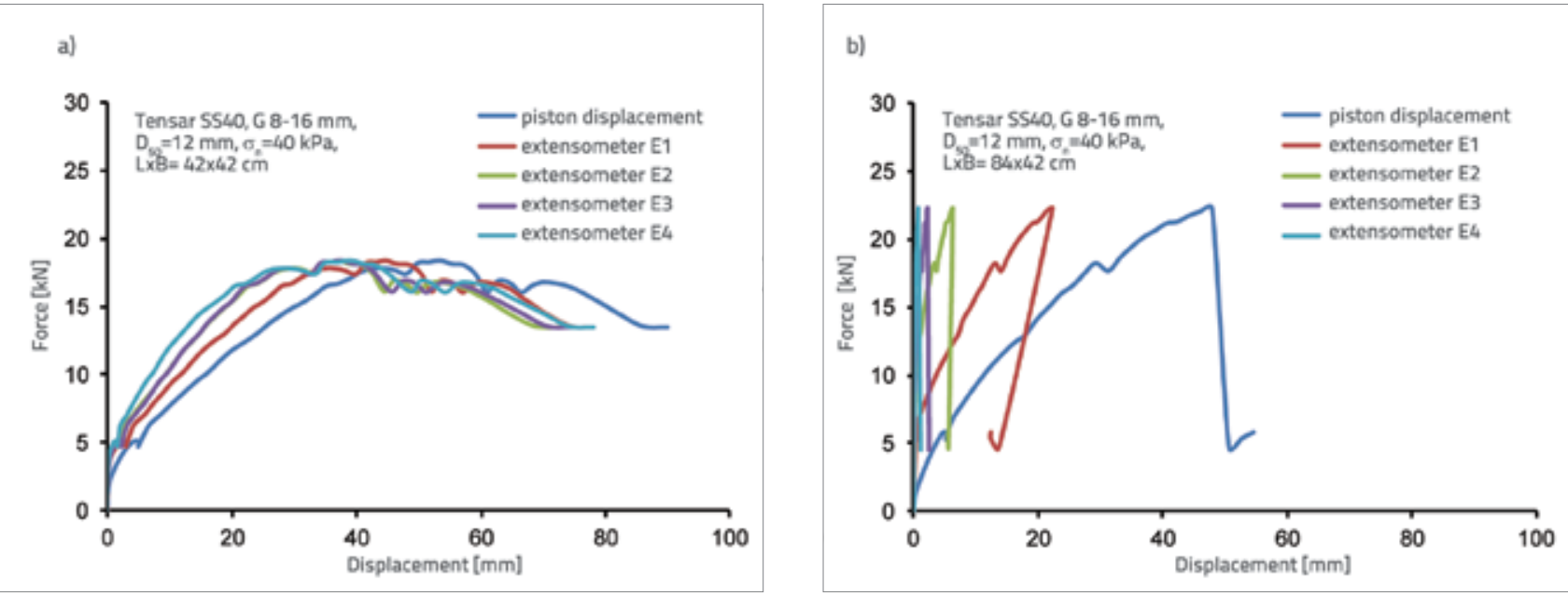

Figure 3. Development of pullout force and displacement at a) pullout; b) reinforcement tensile failure [3]

If friction is the dominating mechanism that occurs at reinforcement pullout, equation (1) for pullout resistance for incoherent soil, according toa [4] is:

$\mathrm{P}=2 \cdot \mathrm{A} \cdot \sigma_{\mathrm{n}} \cdot \mathrm{C}_{\mathrm{i}} \cdot \tan \phi$

where:

$P$ - pullout force,

A - reinforcement surface

$\sigma_{\mathrm{n}}$ - normal stress in the plane of reinforcement sample

$\phi$ - soil friction angle

$C_{i}$ - interaction coefficient (see hereinafter).

\subsection{Influence of boundary conditions and test procedure}

Model testing of reinforced soil by pullout test is sensitive to the influence of boundary conditions of the device, method of sample creation as well as the test procedure. Large dispersion of results from published works is the consequence of using different equipment with different boundary conditions, method of reinforcement installation and soil compaction as well as test procedure, and therefore they are difficult to compare with each other [5]. These influences were the subject of numerous studies, and according to $[1,2,6,7]$ it was estimated that the most significant are: boundary conditions at the box front wall of the pullout device and clamping system for clamping the reinforcement sample, boundary conditions at the upper wall, friction on the side walls (which depends on the box dimensions of the pullout device and reinforcement dimensions) and the method of applying the pullout force. The test results are significantly influenced by the method of soil installation and compaction technique, normal stresses and reinforcement dimensions.

It was shown [1] that the conditions of the box front wall of the pullout device can have a significant impact on test results. Solid top and bottom wall affect load transfer, and can influence the rise of force required to pull out the reinforcement from soil. In order to avoid this, the soil thickness around the reinforcement should be larger than $30 \mathrm{~cm}$, and the vertical load is best to apply by air bag [6]. Clamps for reinforcement clamping should reduce stress concentration and provide a uniform stress distribution across the reinforcement width, to ensure constant contact surface of soil and reinforcement throughout the test, and they can be either out of the device box or within it. [8]. The reinforcement width and distance from the side walls is important because of the possibility of friction at side walls [7]. Minimum distance between the box walls and reinforcement is recommended to be approximately 15 $\mathrm{cm}$ [6]. The influence of friction is reduced by gluing low friction material (Teflon, smooth aluminium, glass, lubricated rubber membrane) on the side walls [8]. According to ASTM standard [9], the box width should be at least $460 \mathrm{~mm}$ and larger than $20 \mathrm{xD}_{85}$ or $6 \mathrm{xD}_{\max }$ of a tested soil sample. The box length should be at least $610 \mathrm{~mm}$ and five times larger than the maximum size of the geogrid mesh [7].

There are two ways of reinforcement pullout from soil: by controlled increase in displacement or force (continuous or incremental force increase). At pullout by a controlled increase in displacement, the pullout rates range from $0.1 \mathrm{~mm} / \mathrm{min}$ [10] to $10 \mathrm{~mm} / \mathrm{min}$ [11], and in most tests it is $1 \mathrm{~mm} / \mathrm{min}$. Farrag [6] shows that the rate below $6 \mathrm{~mm} / \mathrm{min}$ give similar results. Standards prescribe the displacement rate of 1 to $2 \mathrm{~mm} / \mathrm{min}$. In a study with a controlled increase in force, the force increase should not be greater than $2 \mathrm{kN} / \mathrm{m} / \mathrm{min}$ according to ASTM [9]. With an incremental increase in force, increments can be equal or double, and they are maintained for certain time before adding the next increment.

Uniform soil compaction in the pullout device box is very important because without uniform compaction it is difficult to achieve the test repeatability, and pullout force depends on soil compaction. In order to achieve uniform spreading of soil, it is proposed to use a screen with a funnel and flexible tube [2]. Soil compacting is performed by electric vibrating compactors, standard hammer for Proctor test, manual or mechanical compactors. Increase of soil compaction and density increases the possibility of interlock of soil particles in the grid apertures which increases the pullout resistance [6]. Higher compaction under the same test conditions can cause tensile failure of the reinforcement [12]. 
Table 1. Reinforcement pullout test devices

\begin{tabular}{|c|c|c|c|c|c|c|}
\hline $\begin{array}{l}\text { Author, year, } \\
\text { reference }\end{array}$ & $\begin{array}{l}\text { Dimensions } \mathrm{L} / \mathrm{B} / \mathrm{H} \\
(\mathrm{m})\end{array}$ & $\begin{array}{l}\text { Pullout force generation, with } \\
\text { increase } D \text { - deformation (mm/ } \\
\text { min), } \mathrm{N} \text { - stres (description) }\end{array}$ & $\begin{array}{c}\text { Sleeve: exist (yes/no, description, } \\
\text { width (CM)) / clamping system } \\
\text { (description) }\end{array}$ & $\begin{array}{c}\text { Soil thickness } \\
\text { bellow/above } \\
\text { reinforcement } \\
(\mathrm{cm})\end{array}$ & Force and displacement sensors & Compaction and density \\
\hline $\begin{array}{l}\text { Chang et al., } \\
\text { 1977., [19] }\end{array}$ & $1.30,0.91,0.51$ & D & - & - & - & mechanical compaction \\
\hline $\begin{array}{l}\text { Yuan and Chua, } \\
1985 .,[2]\end{array}$ & $0.76,0.71,0.61$ & D (hydraulic) & - & $30 / 30$ & $\begin{array}{c}\text { load cell, } \\
\text { displacement transducers }\end{array}$ & - \\
\hline $\begin{array}{l}\text { Palmeira and } \\
\text { Milligan, 1989., [2] }\end{array}$ & $\begin{array}{c}0.25,0.15,0.15 \\
1.1,1.1,1.1\end{array}$ & $\mathrm{D}(0,5 \mathrm{~mm} / \mathrm{min}$, hydraulic) & $\begin{array}{l}\text { no (just opening on front box } \\
\text { side) // clamps (connected } \\
\text { with bolts and aluminium alloy } \\
\text { to reinforcement) }\end{array}$ & - & $\begin{array}{c}\text { photo measurement of wires } \\
\text { out of box, } 8 \text { load cells on the } \\
\text { front box side, LVDT - on the } \\
\text { piston, load cell }\end{array}$ & $\begin{array}{l}\text { pluvation, vibrocompactor, } \\
\text { cylinders in the box }\end{array}$ \\
\hline $\begin{array}{l}\text { Farrag et al., } \\
\text { 1991., [6] }\end{array}$ & $1.52,0.90,0.76$ & $\mathrm{D}, \mathrm{N}(\max 6 \mathrm{~mm} / \mathrm{min}$ & $\begin{array}{l}\text { yes (width } 30 \mathrm{~cm} \text { ) // clamps } \\
\text { (plates inside sleeve and soil) }\end{array}$ & $\min .30 / 30$ & $\begin{array}{l}\text { LVDT, velocity transducers and } \\
\text { load cells, pressure cell on front } \\
\text { box side }\end{array}$ & $\begin{array}{l}\text { pluvation, mechanical } \\
\text { compaction, nuclear } \\
\text { densimeter }\end{array}$ \\
\hline Marolo, 1993., [21] & $1.60,0.70,0.50$ & $\mathrm{D}(1 \mathrm{~mm} / \mathrm{min})$ & $\begin{array}{l}\text { yes (width } 20 \mathrm{~cm} \text { ) // clamps } \\
\text { (plates inside sleeve) }\end{array}$ & $25 / 15$ & LVDT, load cells & - \\
\hline $\begin{array}{l}\text { Fannin and Raju, } \\
\text { 1993., [22] }\end{array}$ & $1.30,0.64,0.60$ & D & $\begin{array}{l}\text { no // clamps (there is upper } \\
\text { and lower clamp) }\end{array}$ & - & $\begin{array}{c}\text { load cell, } 2 \text { displacement } \\
\text { transducers, piezometers, } 5 \\
\text { extensometers }\end{array}$ & - \\
\hline $\begin{array}{l}\text { Kharchafi, Dysli, } \\
\text { 1993., [23] }\end{array}$ & - & - & - & - & x-ray records & - \\
\hline $\begin{array}{l}\text { Bergado et al. (1994), } \\
\text { [14] }\end{array}$ & $1.30,0.80,0.50$ & D (1 mm/min, hydraulic) & - & & load cell, LVDT & \\
\hline $\begin{array}{l}\text { Koerner et al., } \\
\text { 1994., [4] }\end{array}$ & $1.90,0.91,1.1$ & D, N (1 mm/min, hydraulic) & yes // clamps (no) & $\min .30 / 30$ & $\begin{array}{l}\text { load and displacement } \\
\text { transducers }\end{array}$ & - \\
\hline Min et al., 1995., [24] & $0.6,0.6,0.2$ & $\begin{array}{l}\text { N (hydraulic, electrical, cyclic } \\
\text { load, force increments for } \\
\text { every } 24 \mathrm{~h} \text { ) }\end{array}$ & $\begin{array}{l}\text { no // clamps (grid glued on } \\
\text { metal plates which extend } 10 \\
\mathrm{~cm} \text { in the box) }\end{array}$ & - & $\begin{array}{l}\text { load cells, LVDT at front, } 4 \\
\text { extensometers on grid }\end{array}$ & pluvation \\
\hline $\begin{array}{l}\text { Alfaro et al., } \\
\text { 1995., [25] }\end{array}$ & $1.60,0.50,0.60$ & D & yes // clamps (inside the box) & $25 / 15$ & load cell, LVDT & $\begin{array}{c}\text { mechanical } \\
\text { compaction, weighing }\end{array}$ \\
\hline $\begin{array}{l}\text { Lopes and Ladeira, } \\
1996 .,[26]\end{array}$ & $1.53,0.80,1.00$ & D (hydraulic) & $\begin{array}{l}\text { no or yes (width } 20 \mathrm{~cm} \text { ) // } \\
\text { clamps (exist) }\end{array}$ & $30 / 30$ & $\begin{array}{l}\text { load cell, LVDT, vertical pressure } \\
\text { cell LVDT on grid }\end{array}$ & nuclear densimeter \\
\hline $\begin{array}{l}\text { Ochiai et al., } \\
\text { 1996., [13] }\end{array}$ & $0.6,0.4,0.4$ & $\mathrm{D}(1 \mathrm{~mm} / \mathrm{min}$, reducer, cyclic) & yes // - & - & $\begin{array}{l}\text { load cell, displacement } \\
\text { transducers }\end{array}$ & pluvation \\
\hline Bernal, 1997., [27] & $1.22,0.50,1.22$ & $\begin{array}{c}\mathrm{D}(1 \mathrm{~mm} / \mathrm{min}, 2 \text { hydraulic } \\
\text { cylinders) }\end{array}$ & $\begin{array}{l}\text { yes (width } 15 \mathrm{~cm} \text { ) //clamps } \\
\text { (reinforcement sample in resin, } \\
\text { bolted to two plates) }\end{array}$ & $20,5 / 20,5$ & $\begin{array}{l}\text { load cell, LVDT, } 3 \text { displacement, } \\
\text { transducers on sample, total } \\
\text { cell on box bottom }\end{array}$ & $\begin{array}{l}\text { hand } \\
\text { compaction, weighing }\end{array}$ \\
\hline Cuelho, 1998., [28] & $1.25,1.10,0.90$ & $\begin{array}{l}\mathrm{D}, \mathrm{N}(0-2 \mathrm{~mm} / \mathrm{min} \text {, electrical- } \\
\text { reducer, } 2 \text { air cylinders) }\end{array}$ & $\begin{array}{c}\text { yes (width } 26 \mathrm{~cm} \text { ) // clamps } \\
\text { (plates with reinforcement } \\
\text { samples glued) }\end{array}$ & - & $\begin{array}{l}\text { load cell, extensometers (5), } \\
\text { glued defometers }\end{array}$ & $\begin{array}{l}\text { mechanical } \\
\text { compaction }\end{array}$ \\
\hline Texeira, 1999., [28] & $1.50,0.48,0.70$ & $\begin{array}{l}\mathrm{D}(4,6 \mathrm{~mm} / \mathrm{min}, \text { electrical, } \\
\text { reducer })\end{array}$ & $\begin{array}{l}\text { yes (width } 20 \mathrm{~cm} \text { ) // clamps } \\
\text { (bolted to the reinforcement } \\
\text { samples, passing through } \\
\text { sleeve) }\end{array}$ & - & $\begin{array}{c}\text { load cell, } 3 \text { total cells, } 6 \\
\text { extensometers on the sample, } \\
\text { defometers }\end{array}$ & $\begin{array}{l}\text { vibro compactor, } \\
\text { weighing }\end{array}$ \\
\hline $\begin{array}{l}\text { Alagy awanna et al., } \\
\text { 2001., [29] }\end{array}$ & $0.68,0.625,0.3$ & $\mathrm{D}(1 \mathrm{~mm} / \mathrm{min})$ & $\begin{array}{l}\text { no, sponge to prevent soil } \\
\text { loss, } / / \text { - }\end{array}$ & - & $\begin{array}{l}\text { displacement transducer, laser } \\
\text { sensors for grid displacements, } \\
\text { load cell for vertical and } \\
\text { horizontal direction }\end{array}$ & - \\
\hline $\begin{array}{l}\text { Bergado, Teeraw } \\
\text { attanasuk, 2001., [30] }\end{array}$ & $1.27,0.76,0.51$ & $\mathrm{D}$ (1 mm/min, hydraulic) & - & & - & \\
\hline $\begin{array}{l}\text { Meyer et al., } \\
\text { 2003., [31] }\end{array}$ & $1.5,0.7,0.6$ & $\begin{array}{c}\mathrm{D}(2 \mathrm{~mm} / \mathrm{min} \text {, hydraulic, cyclic } \\
\text { load up to } 4 \mathrm{~Hz})\end{array}$ & $\begin{array}{l}\text { yes (width } 20 \mathrm{~cm} \text { ) // clamps } \\
\text { (reinforcement is rolled or } \\
\text { pulled with two rods) }\end{array}$ & - & 3 load cells on bottom, LVDT & pluvation, weighing \\
\hline Marques, 2005., [32] & $1.53,1.0,0.80$ & (hydraulic) & yes (width $20 \mathrm{~cm}$ ) // - & $40 /-$ & diferent measuring instruments & - \\
\hline $\begin{array}{l}\text { Moraci et al., } \\
\text { 2006., [33] }\end{array}$ & $1.70,0.60,0.68$ & (electrical) & $\begin{array}{c}\text { yes (width } 25 \mathrm{~cm} \text { ) // clamps } \\
\text { (inside soil) }\end{array}$ & & $\begin{array}{l}\text { RVDT (6 on grid sample), load } \\
\text { cell }\end{array}$ & pluvation \\
\hline $\begin{array}{l}\text { Abdelrahman et al., } \\
\text { 2007., [34] }\end{array}$ & $1.20,1.16,0.7$ & (hydraulic, hand) & $\begin{array}{l}\text { no // clamps (two steel plates } \\
\text { with tickness of } 6 \mathrm{~mm} \text { ) }\end{array}$ & - & $\begin{array}{l}2 \text { sensors: } 1 \text { vert., } 1 \text { hor., } 2 \text { LVDT } \\
\text { on sample }\end{array}$ & $\begin{array}{l}\text { weighing, nondestructive } \\
\text { methods }\end{array}$ \\
\hline $\begin{array}{l}\text { Aydogmus, } \\
\text { 2007., [18] }\end{array}$ & $0.6,0.5,0.2$ & $\mathrm{D}(0,000001-12 \mathrm{~mm} / \mathrm{min})$ & no // clamps (outside the box) & cca $10 / 10$ & $\begin{array}{l}\text { load cell, pressure measurement } \\
\text { at box bottom and in airbags }\end{array}$ & $\begin{array}{c}\text { mechanical } \\
\text { compaction, weighing } \\
\text { system on the box bottom }\end{array}$ \\
\hline $\begin{array}{l}\text { Abdelouhab et al. } \\
\text { 2008., [35] }\end{array}$ & $2.0,1.1,1.1$ & - & - & - & $\begin{array}{l}\text { load cell and total cell } \\
\text { (front and bottom box side) }\end{array}$ & - \\
\hline $\begin{array}{l}\text { Requirements of EN } \\
13738,2004 .,[17]\end{array}$ & $1.50,0.60,0.30$ & $\begin{array}{c}\mathrm{D}, \mathrm{N}(2 \pm 0,2 \mathrm{~mm} / \mathrm{min} \\
\text { hidraulički) }\end{array}$ & $\begin{array}{l}\text { yes (width } 20 \mathrm{~cm} \text { ), clamps } \\
\text { (articularly connected) }\end{array}$ & $\begin{array}{l}6 \times d_{\max } / \\
6 \times d_{\max }\end{array}$ & LVDT, load cells & $\begin{array}{l}\text { mechanical } \\
\text { compaction }\end{array}$ \\
\hline $\begin{array}{l}\text { Requirements of GRI } \\
\text { GT6, 1991., [16] }\end{array}$ & $\begin{array}{l}1.20,0.75,0.60 \\
\text { or }>20 \times d_{85}\end{array}$ & $\mathrm{D}(1 \mathrm{~mm} / \mathrm{min})$ & $\begin{array}{c}\text { yes (width } 15 \mathrm{~cm} \text { ) // clamps ( } 2 \\
\text { plates width } 20 \mathrm{~cm} \text { ) }\end{array}$ & $\min .30 \mathrm{~cm}$ & LVDT, measuring ring, load cells & pluvation, mechanical \\
\hline
\end{tabular}




\subsection{Existing pullout test devices}

Over past thirty years many researchers around the world were developing the devices for pulling out the reinforcement from soil. The literature finds more than 30 such devices, and an overview of devices in terms of dimensions and technical test capabilities is given in Table 1. These are pullout devices with small (e.g. $\mathrm{LxBxH}=0,25 \times 0,15 \times 0,15,[2]$ ), medium (e.g. $\mathrm{LxBxH}=$ $0,6 \times 0,4 \times 0,4 \mathrm{~m},[13])$, and large boxes (e.g. $\mathrm{LxBxH}=1,3 \times 0,8 \times 0,5 \mathrm{~m}$, [14]) into which soil and reinforcement are installed ( $L, B$ and $H$ = length, width and height of the box). Most of them are large pullout devices, with the box volume of 1-2 $\mathrm{m}^{3}$. Large pullout devices have dimensions from 1 to $2 \mathrm{~m}$ (average $1.5 \mathrm{~m}$ ), width of 0.5 to $1.2 \mathrm{~m}$ (average $0.8 \mathrm{~m}$ ) and the height of 0.4 to $1.1 \mathrm{~m}$ (average $0.7 \mathrm{~m}$ ). In large pullout devices costs of test are high, and the process of soil installation and extraction is time consuming and demanding (soil installation and compaction is performed in layers with thickness $5-10 \mathrm{~cm}$ with achieving uniform compaction throughout the volume, which can last 1-2 days). There is a large number of studies carried out using sand as a filler, although for engineering applications soil with coarse grains (e.g. gravel) are more suitable because they are more frequently used in the reinforced soil structures. When using coarser-grain soil testing needs to be carried out in a big pullout device, which emphasizes its importance [15]. The standards: ASTM D6706-01 [9], GRI Test Method GG5 [16] and EN 13738 [17] were developed for pullout tests - test requirements indicated in standards are shown at the bottom of Table 1. Recently, universal devices for testing soil and reinforcement interaction are developed that allow several types of tests: direct shear, pullout and tensile test of reinforcement [18].

\subsection{Large pullout devices, type GFOS}

A large pullout test device (the device layout and cross-section are shown in Figure 2 and appearance in Figure 4) has been developed at the Faculty of Civil Engineering in Osijek. The box size is $\mathrm{LxBxH}=$ $1,9 \times 0,9 \times 1,2 \mathrm{~m}$, making it one of the larger pullout devices. Normal stresses are applied using airbags mounted inside the device cover (Figure 5a). The impact of the front wall is reduced by a sleeve having width of $30 \mathrm{~cm}$ at the front wall (Figure 5b).

Pullout of the reinforcement installed in soil in the horizontal plane at the box half height is achieved by an electric motor and gearbox. Soil is placed in the box in layers with thickness of $5 \mathrm{~cm}$ and compacted manually or by vibro-compactor. Tests are carried out at controlled displacement rate of $2 \mathrm{~mm} / \mathrm{min}$, and pullout force (max. $80 \mathrm{kN}$ ) is measured by a load cell. Reinforcement displacements are measured by extensometers: on the pullout cylinder and in four points on the reinforcement (E1-E4, Figure 2). Besides the reinforcement displacements, it is also possible to measure the displacements in soil above the reinforcement to detect thickness of the zone in soil around reinforcement in which reinforcement influence is reflected (EV1-6, Figure 2). New to the concept of measurement is the measurement system of velocity of compression and shear waves by accelerometers in the soil at different levels, above and below the plane of reinforcement, which gives the velocity distribution of these waves in soil, and thus the change in soil stiffness can be also indirectly determined per height resulting from the soil and reinforcement interaction. This device enables testing of coarse grain soil (so far conducted tests on soils with $D_{\max }=32 \mathrm{~mm}$ ).

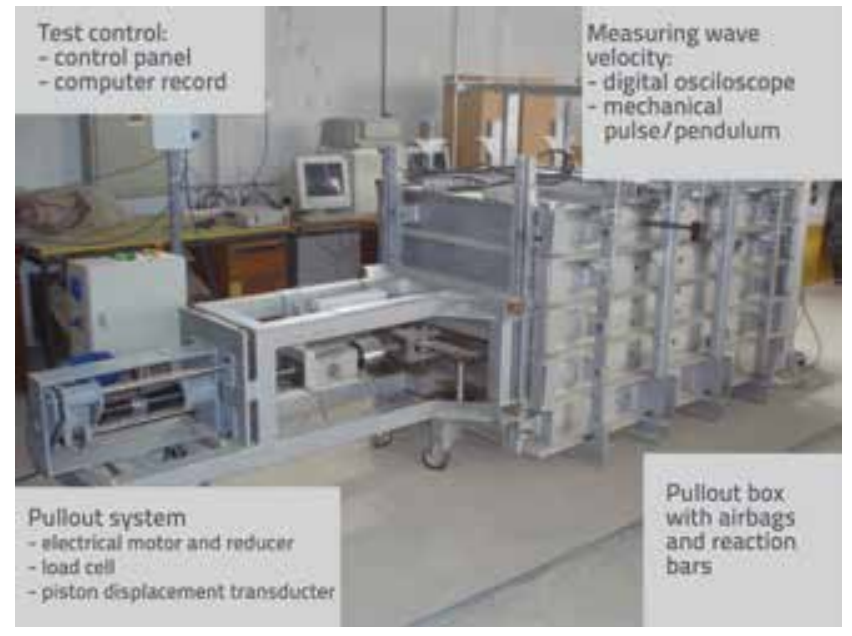

Figure 4. Large pullout device, type GFOS
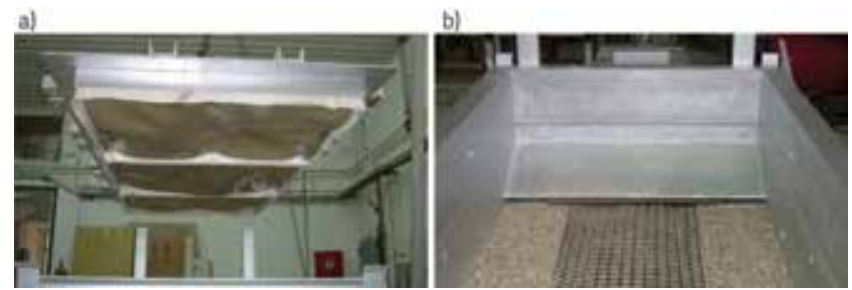

Figure 5. Pullot device type GFOS; a) Cover with air bag, b) sleeve for reducing the front wall influence

\section{Analysis of model test of reinforcement pullout from soil}

\subsection{Interaction mechanisms at reinforcement pullout from soil}

Studies of interaction mechanisms between soil and reinforcement at pullout began with studying of geotextiles pullout from sandy soil where it was found that friction was dominant in pullout resistance. When geogrids are used, which are nowdays prevailing in the reinforced soil structures, besides friction there are other mechanisms arising from the existence of longitudinal and transverse ribs, knots and apertures in the grid. Interaction mechanisms at pullout of the geogrid from soil can be (Figure 6):

a) friction of soil particles over the reinforcement (similar mechanism as for geotextiles),

b) friction of soil particles on soil interlocked in grid apertures, c) passive soil resistance to the grid transversal ribs [36]. 
a)
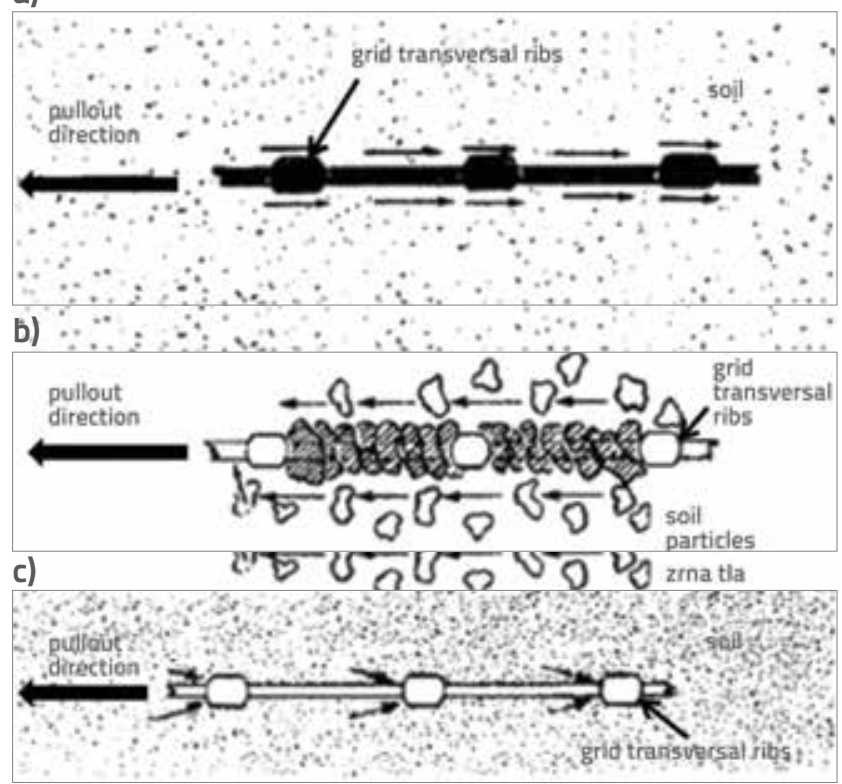

Figure 6 Mechanisms of soil and goegrid interaction: a) friction at contact with grid, b) friction of soil particles on soil "interlocked" in grid apertures, c) effect of passive soil resistance to the transverse ribs [36]

Figure 7 shows influence of differentmechanisms of soil-reinforcement interactions depending on the type of reinforcement [6]. When reinforcement is used, shear occurs at the contact with soil at small deformations, and passive resistance in soil in front of the grid transversal ribs develops with increase of displacement [37].

\begin{tabular}{|c|c|c|c|c|c|c|}
\hline $\begin{array}{c}\text { Main } \\
\text { phenomenon }\end{array}$ & $\begin{array}{c}\text { 3-0 } \\
\text { strips }\end{array}$ & \begin{tabular}{|c|}
$\begin{array}{c}2-0 \\
\text { grids: } \\
\text { wire, rods }\end{array}$ \\
\end{tabular} & \begin{tabular}{|l|}
$2-0$ \\
geogrids \\
\end{tabular} & \begin{tabular}{|c}
-0 \\
geotextille \\
wowen
\end{tabular} & \begin{tabular}{|c|c|}
$\begin{array}{c}\text { 1-D } \\
\text { geotertile } \\
\text { nonwower }\end{array}$ \\
\end{tabular} & 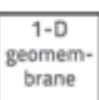 \\
\hline $\begin{array}{l}\text { Interlocking } \\
\text { "№ng } \Rightarrow\end{array}$ & & $\begin{array}{l}\text { ?particle } \\
\text { sizer/apert } \\
\text { ure size }\end{array}$ & $\begin{array}{l}\text { ?particle } \\
\text { izz/apert } \\
\text { ure size }\end{array}$ & $\boldsymbol{\Delta}_{40-20 \% 6}$ & $\underbrace{\boldsymbol{\Delta}}_{40-20 \% 6}$ & \\
\hline \multicolumn{7}{|l|}{ 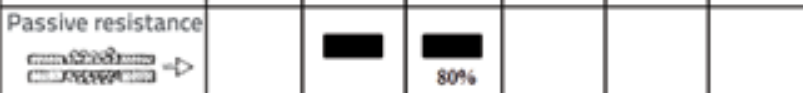 } \\
\hline 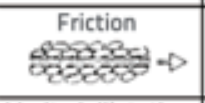 & & $\boldsymbol{\Delta}_{2006}$ & $\boldsymbol{\Delta}_{2006}$ & $60-8006$ & 60.8006 & \\
\hline $\begin{array}{l}\text { Limited dilatation } \\
\text { (n) }\end{array}$ & $\square$ & $\square$ & $\square$ & $\triangle$ & $\Delta$ & \\
\hline \multicolumn{2}{|c|}{$\begin{array}{l}\text { Combined: friction+elongation } \\
-1 \\
-1\end{array}$} & & $\Delta$ & $\Delta$ & $\Delta$ & $\Delta$ \\
\hline 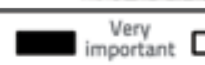 & & & & & & \\
\hline
\end{tabular}

Figure 7. Mechanisms of soil and geosynthetics interaction [6]

By pullout tests it was shown that, depending on the reinforcement type and the type (and size) of soil particles, additional pullout resistance can arise due to prevented possibility of soil dilatation [6]. In case of appropriate ratio between the soil grain size and geogrid geometrical characteristics (aperture size, rib shape and thickness) soil grains may be interlocked in soil apertures which increases the soil stiffness [38-41] and increases the pullout resistance.

The view point of the authors of this paper, which is in line with the Giroud's conclusions [42], is that the geogrid and soil interaction of can be observed on the basis of: a) increased soil stiffness around geogrid which occurs as a result of soil grains interlocking in geogrid apertures and b) pullout resistance due to friction and passive resistance of transversal ribs. The grid strain is required to achieve any kind of interaction. It can occur as a result of stresses in ribs that form the geogrid aperture during soil compaction and due to effects of vertical overlay load (or additional stresses, for example: from road traffic), when soil particles are interlocked in the geogrid aperture and cause rib's strain. The geogrid deformation can also occur as a consequence of the relative displacement of the geogrid and soil at geogrid pullout (i.e. when geogrid acts as anchor in retaining structures or embankment slopes and landslides repaired by soil reinforcement). Soil particle interlocking in geogrid apertures also contributes to the geogrid pullout resistance.

\subsection{Review of various effects on testing results}

Soil and reinforcement interaction depends on physical and mechanical properties of soil (grain size distribution, shear strength, grain shape, degree of compaction and density) and reinforcement (type: geotextile, geogrid, production method: glued or extruded geogrid, woven or non-woven geotextile, geometric characteristics: thickness of longitudinal and transverse ribs, existence of thicker nodes; geogrid aperture size, mechanical properties: tensile strength, surface roughness, radial secant stiffness [43]). The relationship between soil properties and reinforcement proprerties (ratio of the aperture size in relation to the soil particles size, or ratio of the geogrid rib thickness to the soil particles) has special influence on the interaction, as well as the state of stress and deformations. An overview of different influences on tests results, such as the impact of normal stresses and dimensions of reinforcement, reinforcement types, soil types and the impact of geometric relationships of soil and reinforcement will be presented hereinafter.

\subsubsection{Influence of normal stresses and dimensions of the reinforcement sample}

In addition to degree of compaction, normal stresses caused by the overlay weight $\left(\sigma_{n}\right)$ have a great influence on the pullout resistance and impact directly on development of shear stresses at the soil - reinforcement contact, as well as to the extent of the interlocking effect. Whether the reinforcement will be pulled out from soil or it will experience tensile failure depends on the normal stress level and its increase will change the displacement distribution along the reinforcement: the largest displacements occur on the part closer to the pullout point from soil, and drop sharply toward the end of the sample. Increase in $\sigma_{n}$ prevents the soil dilatation and increases 
friction and passive resistance of the grid transversal ribs which increases the overall pullout resistance [6]. Impact of $\sigma_{n}$ in sand can be seen in Figure 8: reinforcement can experience full pullout $\left(\sigma_{n}=12.5\right.$ and $25 \mathrm{kPa}$ ), tensile failure after partial pullout $\left(\sigma_{n}=50 \mathrm{kPa}\right)$ or tensile failure without pullout $\left(\sigma_{\mathrm{n}}\right.$ $=75$ and $100 \mathrm{kPa}$ ). It can bee seen that the increase in the pullout resistance due to increase in normal stresses is not linear and depends on the type and characteristics of soil and reinforcement, and it should be determined for each individual case of use of certain reinforcement in a particular soil.

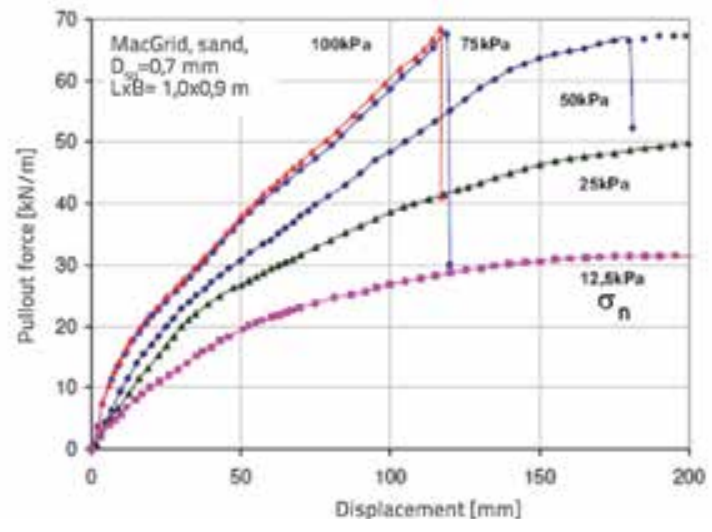

Figure 8. Pullout force increase at normal stresses increase, [12]

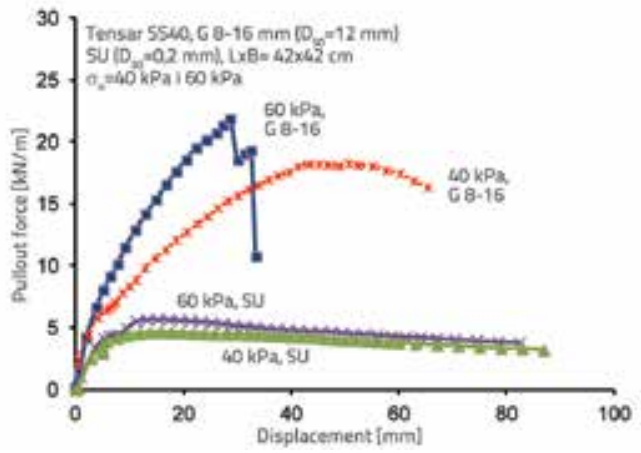

Figure 9. Differences in pullout force for normal stresses of 40 and 60 $\mathrm{kPa}$ in gravel and sand [3]

a)

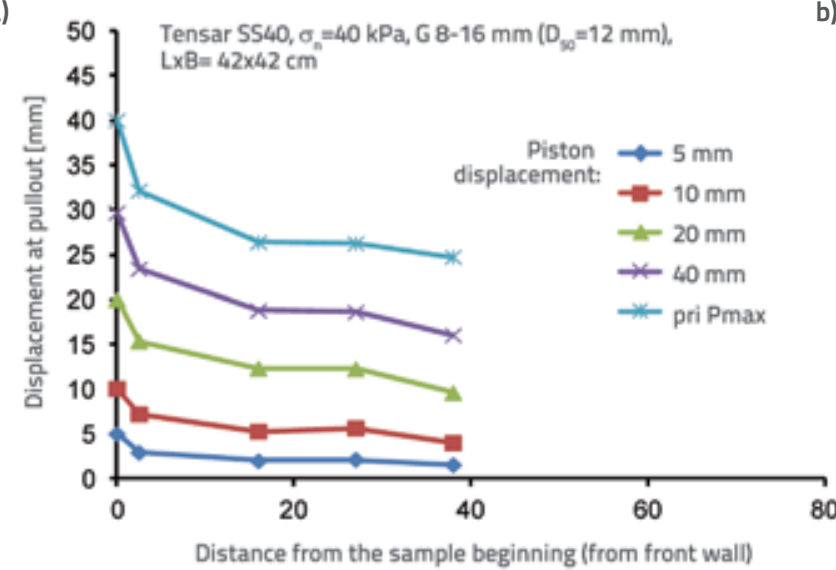

Figure 9 shows that in gravel, when $\sigma_{\mathrm{n}}$ rises from 40 to $60 \mathrm{kPa}$, the reinforcement fails in tension instead of pullout, while pullout in sand occurs at $\sigma_{n}=40$ and $60 \mathrm{kPa}$, with significantly less pullout forces [3]. By increasing of normal stresses only the first few rows of the geogrid transversal ribs are activated and pullout forces is controlled by its tensile strength $[3,12,14]$. Dimensions and relationship of the reinforcement length $(L)$ and width (B) have large impact on the pullout resistance and failure mode. Excessive length in relation to the width may indicate that the reinforcement will undergo tensile failure, and not pullout. Under the provisions of pullout standards, the L/B ratio should be higher than 2 according to [9], or 3, according to [17]. Results of pullout tests [3], at $\mathrm{s}_{n}=40 \mathrm{kPa}$ from Figures $3 \mathrm{a}$ and $3 \mathrm{~b}$ show the reinforcement pullout for the ratio $L / B=1$, while tensile failure occurs at $L / B=2$. For the $L / B=1$ ratio displacement along the entire reinforcement length appear even at small displacements of the front part of the reinforcement (Figure 10a). As pullout continues, displacements along the entire length rise and pullout occurs. For the $\mathrm{L} / \mathrm{B}=2$ ratio (Figure $10 \mathrm{~b}$ ) displacements decline rapidly from the beginning to the end of the reinforcement and disappear at the sample end. In this case the reinforcement tensile failure occurs. Studies made by Sobhi and Wu [44] speak of "activated length" of the sample: at certain pullout force displacements occur only on a part of the reinforcement length, and the activated length increases with increasing force, but tensile failure may occur before activating the entire reinforcement and its pullout from soil. If pullout is preferred to be achieved and not tensile failure, which is important in determining the interaction coefficients with geogrid bearing in two directions in gravels, tests shall be carried out with a reduced value of the $L / B$ ratio in relation to the recommendations of the standards, and the proposal based on $[3,45]$ is: $L / B=1$.

\subsubsection{Influence of the reinforcement type}

Studies on the reinforcement influence on the interaction with soil by pullout tests begun on geotextiles, and recently most of studies are done on geogrids. Larger number of studies was

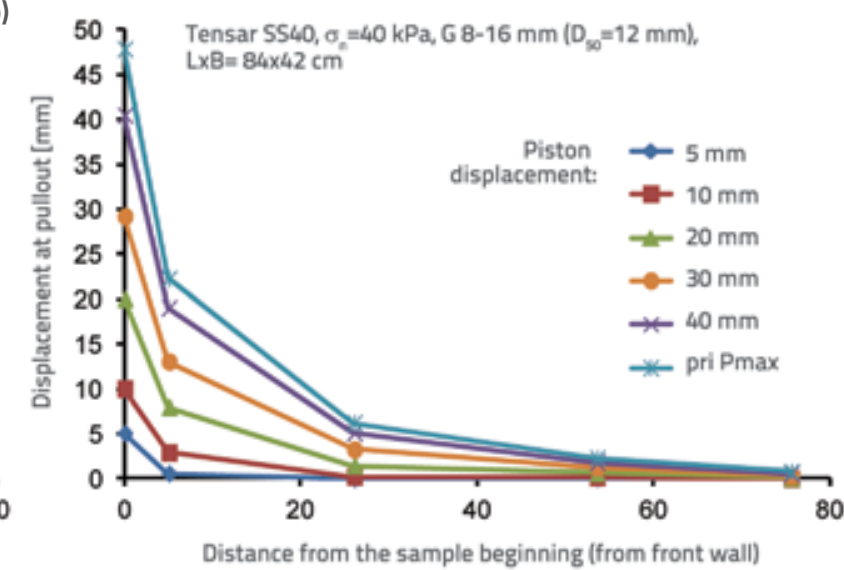

Figure 10. Displacement development along the geogrid sample length where a) $L / B=1$ and $b) L / B=2[3]$ 
done on geogrids bearing in one (longitudinal) direction for example $[6,7,12,13,20,25,26,28,31,33,34,37]$, and less studies were done on geogrids which bearing in two (both) directions for example, [3, 8, 13, 24, 27, 29, 31, 34, 43, 45]. Studies also include tests of metal grids (rectangular [1, 3], or hexagonal meshes [12, $30,46])$, geotextiles, [8,20,23, 27, 44, 47] geomembranes [3] or metal plates $[3,15]$. Comparison of behaviour of geotextiles and geogrids at pullout in Figure 11 shows that the pullout resistance of geogrid is almost twice higher than that of geotextile [47].

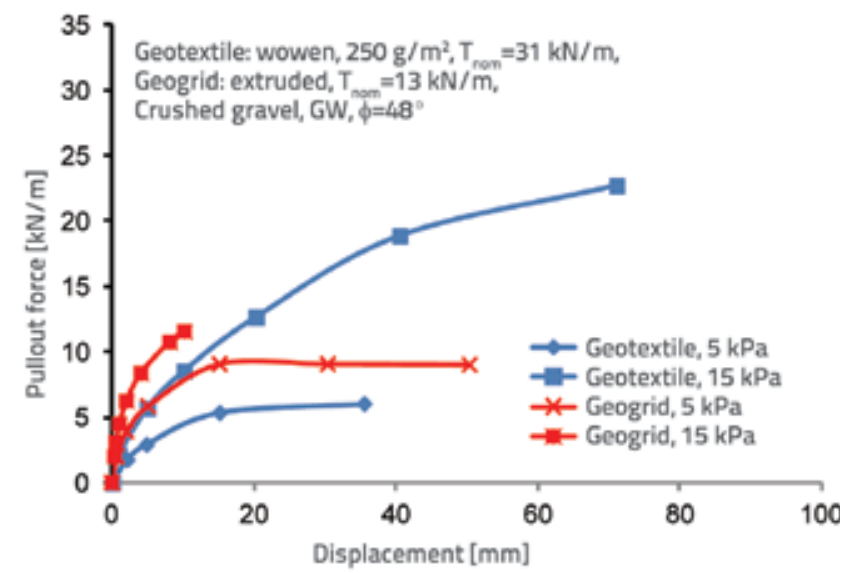

Figure 11. Pullout comparison of geogrid and geotextile [47]

For geogrids, in addition to tensile strength, the geogrid stiffness has also strong influence on behaviour during pullout (the value of pullout force and reinforcement deformations), and the difference can be made for stiff and elastic geogrids. Figure 12 shows the stress and displacement relationship of metal geogrids that may be considered stiff compared to the extensible polymer geogrids. For metal geogrid maximum pullout force is achieved at lower displacement values than in polymer geogrids, and after reaching the peak value, the pullout force declines with the displacement increase. Simultaneous activation of the entire grid length occurs, and after the initial displacement soil behind the grid transverse ribs is loosened thus facilitating further geogrid penetration through soil. For extensible polymer geogrids the pullout force value increases with displacement up to the maximum value of pullout force that is achieved only at larger displacements. The continuing increment of the pullout resistance can be explained by the gradual activation of rows of the geogrid transverse ribs, so that rows of ribs closer to the pullout point are activated first, followed by other rows. Comparison of the shape of pullout curve in Figures 12a and $12 \mathrm{~b}$ reveals that polymer geogrids have a similar response to pullout, while the metal grid in the study [3] did not show so pronounced loss of force after pullout is reached [1] which can be attributed to different test conditions (soil type and compaction, geogrid type). Metal grids develop higher resistance at smaller deformations than polymer grids.

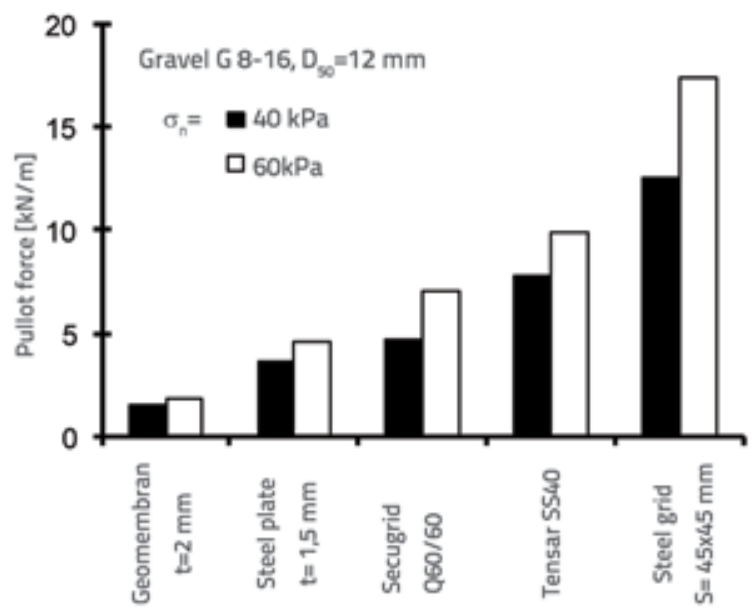

Figure 13. Comparison of maximum pullout forces for various types of reinforcement [48] a)

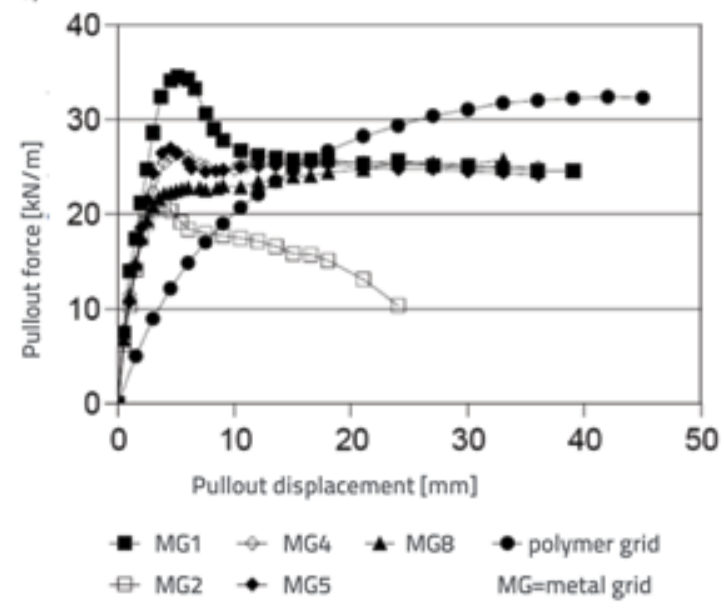

b)

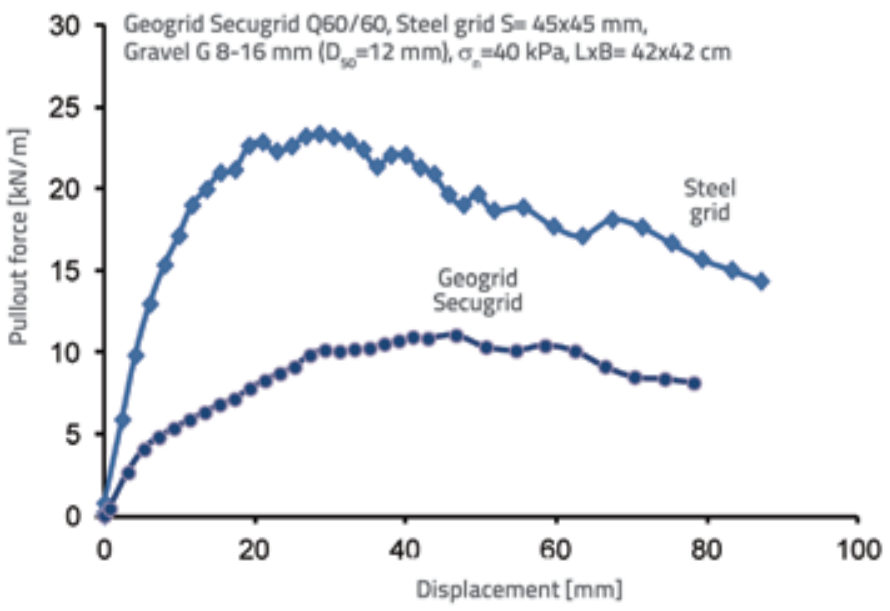

Figure 12. Results of pullout tests on the large sample of metal and polymer geogrid for metal and polymer geogrids: a) according to [1]; b) according to [3] 
Behaviour of planar reinforcement at pullout (geotextiles, geomembranes, metal plate), where pullout resistance comes from friction, is significantly different from the behaviour of a geogrid. The values of pullout forces in Figure 13 show that pullout forces for polymer geogrids and steel grid are significantly greater than the pullout force for the steel plate and geomembrane $[3,48]$. The ratio of pullout forces applied to geogrids / geomembranes is approximately 4.5, while the ratio of pullout forces for steel grid / plate is approximately 3.5.

The difference in behaviour exists in uniaxial geogrids and biaxial geogrids which was investigated by Lopes [37] comparing it with behaviour of geotextiles (Figure 14). Uniaxial geogrids (GG1 and GG2) achieve higher forces at pullout than a biaxial geogrid in (GG3), because they have a higher tensile strength, and pullout is achieved only in the highest tensile strength geogrid (GG2), while other geogrids experience tensile failure. It should be noted that all geogrids have a similar behaviour to the failure, and that's because fine grain soil was used in test and because the interlocking effects are not pronounced in such soil.

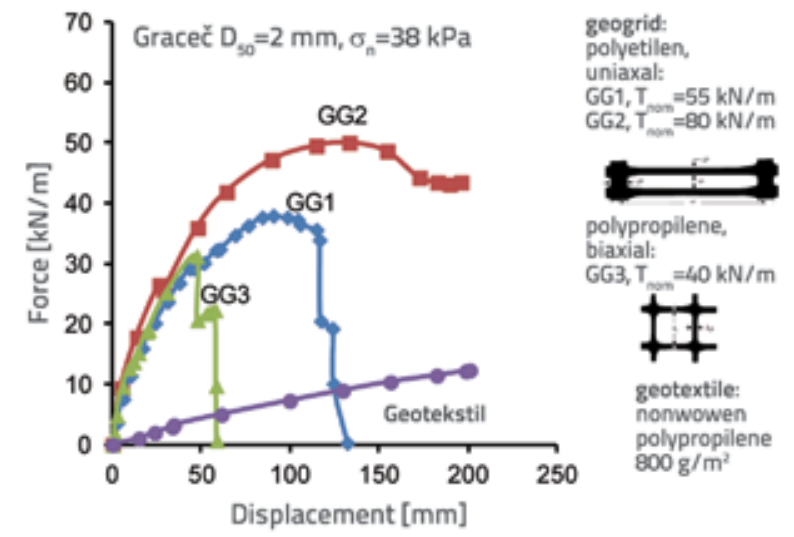

Figure 14. Comparison of development of pullout force and displacement for geogrids bearing in one and in two directions with geotextile, [37]

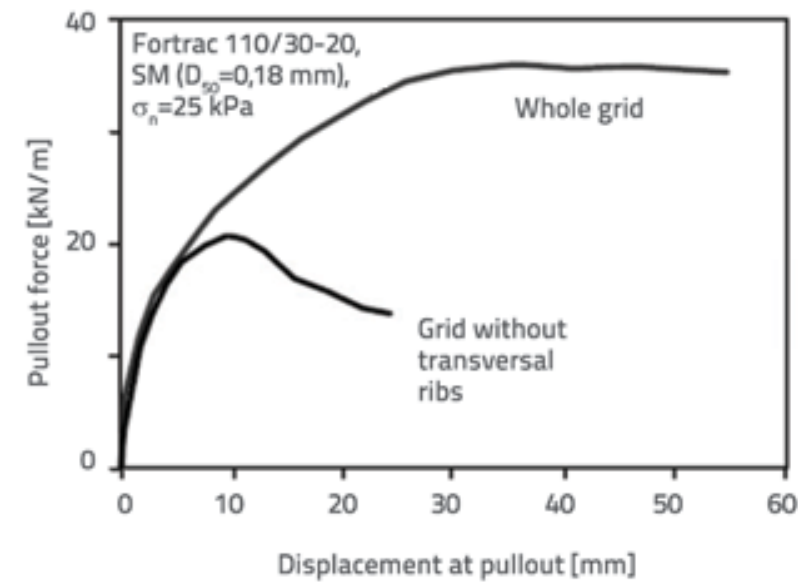

In addition to stiffness, behaviour at pullout significantly depends on the geometrical characteristics of geogrid with special influence transversal ribs [1]. Figure 15a shows the results of pullout tests for a geogrid with transversal and longitudinal ribs (complete sample) and a geogrid where transversal ribs were removed. It is shown that transverse ribs are accounted for taking a significant portion of pullout force, but friction on longitudinal ribs is equally important [49]. A similar ratio of pullout force for the grid with transversal ribs and without them for the geogrid in gravel were obtained by the authors of this paper, as shown in Figure 15, although the achieved pullout forces were higher. The results obtained by numerical modelling of the geogrid pullout from sand indicate a major impact of transversal ribs [50]. Contrary, the results of reinforcement pullout in the big pullout apparatus with geogrids show that the contribution of transversal ribs in sand is smaller [3].

Pullout tests on insulated transversal ribs of geogrids in compacted sands with a high ratio of rib thickness and sand grain diameter show that the soil failure occurs in front of the rib at a distance of up to 6 times the thickness of a transversal rib, and for a large apertures grid (small contact surface of ribs compared to the total area of the sample) it is shown that for the greater distance between the transversal ribs, there is less of their mutual influence [2]. The metal grids with round transversal ribs show that, at the ratio of the spacing of transverse ribs (S) and rib thickness (B) S / B > 40 interference becomes negligible [1]. For grids with hexagonal apertures passive resistance of transversal ribs is 4-6 times greater than the friction on the whole sample [46]. Elements affecting the grid behaviour at pullout include the shape and transverse rib stiffness [1]. For geogrids with transversal ribs of small flexural stiffness progressive mobilization of passive resistance in soil in front of them occurs with increase of pullout force and bending of transverse ribs [51].

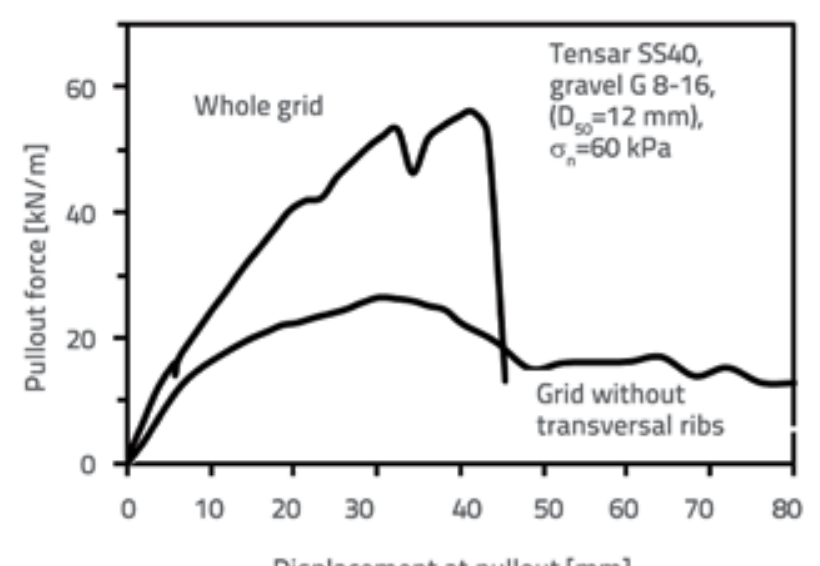

Displacement at pullout [mm]

Figure 15. Influence of transversal ribs on geogrid pullout: a) according to [49]; b) according to [3] 


\subsubsection{Influence of soil type and soil and reinforcement properties}

Soil properties used in reinforced soil structures directly affect its behaviour. In construction of e.g. road embankments, noncohessive soils are preferred due to favourable mechanical properties (high strength and low compressibility, lower impact of moisture changes on mechanical properties). Zornberg and Mitchell [52] mention disadvantages of using coherent soils and soils with high proportion of fine particles in construction of road embankments because of low strength, variability in moisture content and high deformability. However, in actual situations there is often no sufficient quantity of quality fill materials in the vicinity of a building site, and therefore poor quality materials become increasingly subject of interest for use as a fill in the reinforced soil structures.

There is relatively small number of studies of reinforced soil by pullout test in coherent soils, mainly oriented to studying the soil moisture content impact of on the pullout force. If soil moisture increases pullout force decreases (CH clay, Figure 16), and this decline is more significant at normal stress of 60 $\mathrm{kPa}$ than $30 \mathrm{kPa}$, where the pullout force is the same for both values of normal stress ( 60 and $30 \mathrm{kPa}$ ) for moisture content of more than $27 \%$. [53].

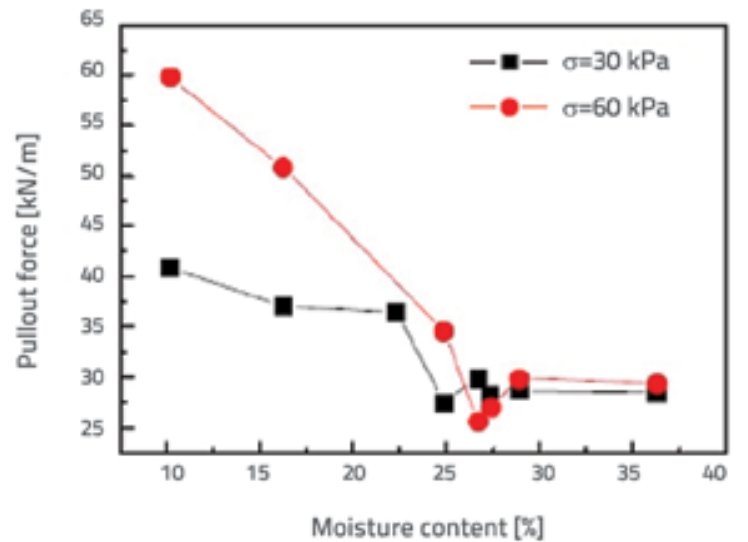

Figure 16. Dependency of the pullout force on moister content change in coherent soil [53]

There is a large number of studies of reinforced soil by pullout test in sand, although larger grain soils (e.g. gravel, either natural or crushed material) are far more frequently used in geotechnical projects. The influence of larger grain diameters on interaction with different reinforcement types was also researched by the authors of this paper $[3,40]$ in their study. Figure 17 shows the influence of the soil grain diameter on pullout force for metal grids (MG) with square apertures of sizes of $S=22,45$ and $90 \mathrm{~mm}$, extruded polymer geogrid (PG) and metal plate $(\mathrm{MP})$ in sand $\left(\mathrm{D}_{50}=0.2 \mathrm{~mm}\right)$ and three natural rounded gravels $\left(D_{50}=6,12\right.$ and $\left.25 \mathrm{~mm}\right)$. It can be noted that the pullout force rises with increase in the soil grain diameter ,except in metal grid with $\mathrm{S}=22 \mathrm{~mm}$ when the soil grain size becomes larger than the size of, and instead of being interlocked in apertures soil grains slide along its surface.

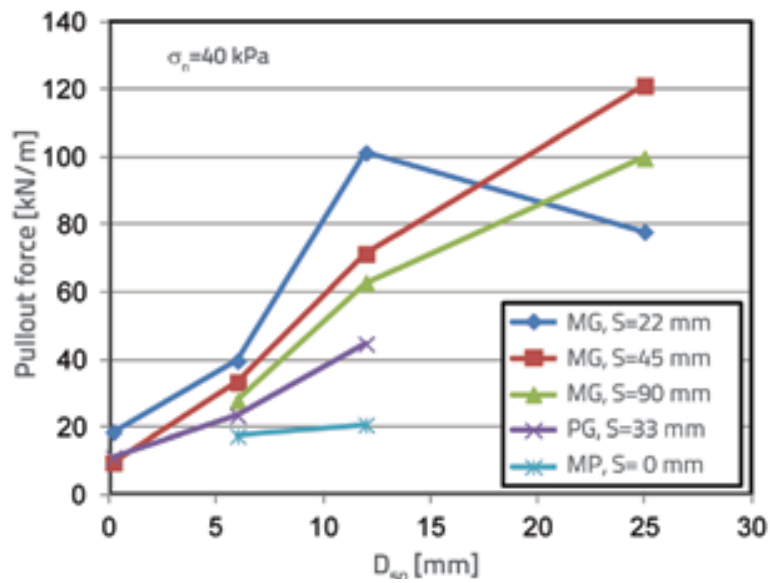

Figure 17. Influence of soil grain diameter on pullout force in metal and polymer grids and metal plate [3]

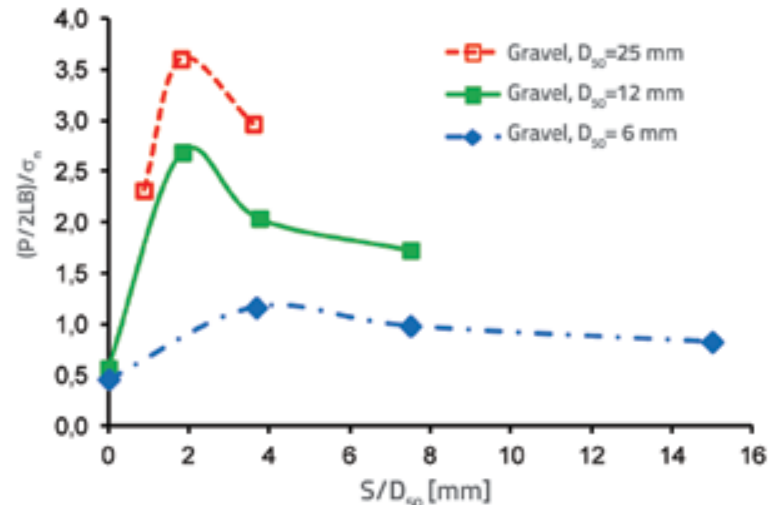

Figure 18. The pullout resistance as function of $S / D_{50^{\prime}}$ [55]

Although a large number of studies by pullout tests were made, relatively few results analyzing the impact of the ratio of the reinforcement geometric characteristics and soil grain size have been published. Palmeira and Milligan [2] studied the effect of the $B / D_{50}$ ratio $(B=$ height of transversal ribs, $D_{50}=$ typical grain diameter) and concluded that in metal and polymer geogrids only at the $B / D_{50}$ ratio between 10 and 15 the pullout resistance becomes independent on the soil particles size (uniform Leighton Buzzard sand with $D_{50}=0.4$ to $1.6 \mathrm{~mm}$ is used). The pullout resistance significantly depends on the $S / D_{50}$ ratio $(S=$ size of grid apertures expressed as the distance between grid transversal ribs). The study results show that for medium to fine silica sand $\left(D_{50}=0.6 \mathrm{~mm}\right)$ and grids made by drilling holes in geomembrane $(\mathrm{S}=30-100 \mathrm{~mm}$ ), at $S / D_{50}=50$ maximum pullout resistance is achieved [34]. Similar observation by [4] and [54] applies to the ratio $S / D_{50}$ ' 3. In their studies on metal and polymer geogrids in gravels $\left(D_{50}=6-25 \mathrm{~mm}\right)$ the authors of this paper showed that the highest pullout resistance of geogrid is achieved at the ratio $S / D_{50} \approx 2$ (Figure 18) $[3,55]$. 


\subsubsection{The zone of reinforcement influence and reinforced soil stiffness}

In reinforced soil it is important to know what is the thickness of the soil zone influenced by the geogrid. It was studied by Dyer [56] in his photoelastic studies at pullout and later by other researchers using numerical models (e.g. [14,32,39,57]). These studies showed the presence of changes in stresses and displacements in soil caused by the reinforcement pullout. Experimental determination of the zone of reinforcement influence on the surrounding soil was made by authors [3] and [38]. By measuring displacement in soil in the vicinity of the geogrid Minažek [3] found that the reinforcement influence extends approximately to the distance of $30 \mathrm{xD}_{50}$ measured vertically from the geogrid plane. On one test example whose results are shown in Figure 19 (a) it is noted that the height of the reinforcement influence is $15 \mathrm{~cm}$.

The zone of reinforcement influence can be defined by the distance from the reinforcement plane where soil has higher stiffness than in case when it is not reinforced. Vertical spacing of geogrids in the structure should be adjusted to the zone of influence. Theoretically, each geogrid should have its own "footprint" of interaction in a given soil which is reflected by the degree of soil improvement and with size of the zone of influence. Such geogrid property can be determined by measuring the velocity of compression and shear waves in reinforced soil. This hypothesis is the subject of years of research at Faculty of Civil Engineering Osijek. Attempts to determine the stiffness of the reinforced soil composites applying the geophysical method by measuring the velocity of compressed and shear waves in the laboratory environment by pullout test are illustrated in Figure 19b where the increase of waves velocity in soil is noticed when geogrid is present [41]. This approach is used for the first time to study the reinforced soil and requires additional improvement of measurement techniques in order to obtain reliable and applicable results.

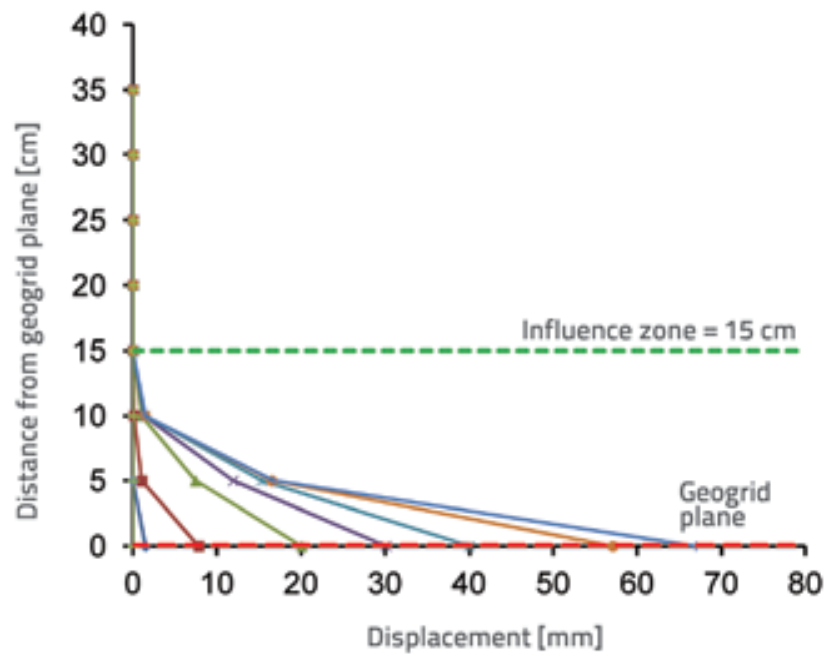

\subsection{Comparison of model studies of reinforced soil by pullout test with field tests and numerical solutions}

There are few of studies with direct comparisons of the field and model pullout test [13,58,59]), although they would be very useful in assessing the applicability of the model test results for design of reinforced soil. Field pullout tests are carried out on specifically prepared test sections of the reinforced soil structures, as shown in Figure 20.

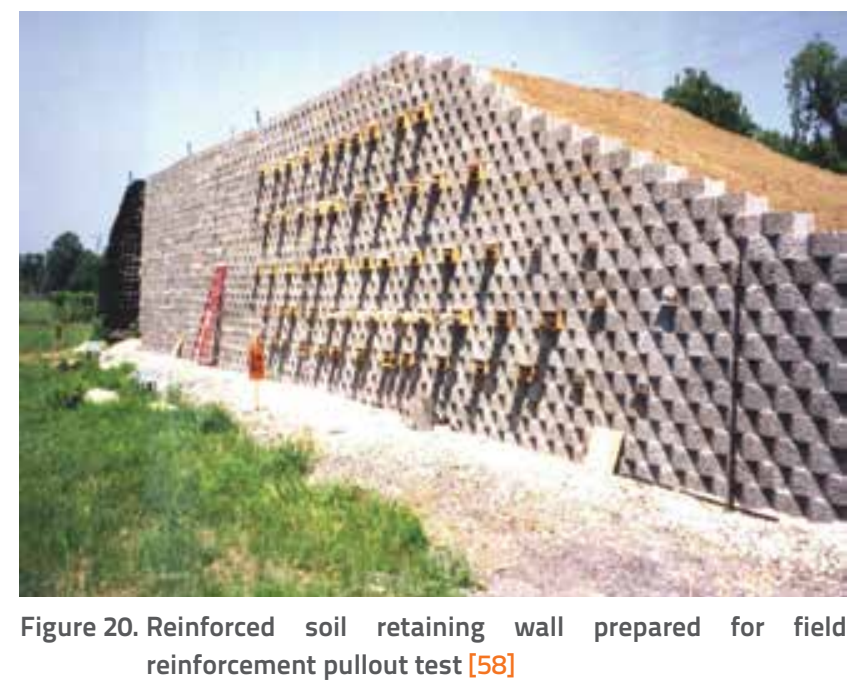

In comparison with the model pullout test, they have certain restrictions relating to the quality of soil installation (homogeneous compaction in the entire soil volume), or the ability to determine accurately the influence of the front wall and values of normal stresses in order to be able to reproduce them in the model test. Comparison of results of field and

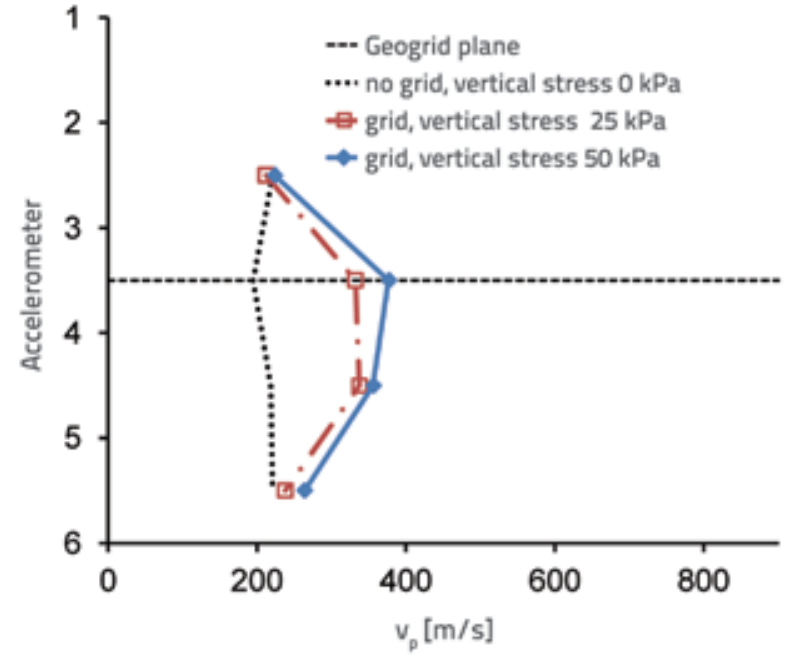

Figure 19. a) Displacements in soil above the reinforcement plane occurring at the reinforcement pullout and indicate the soil zone thickness influenced by the reinforcement pullout [4]; b) Comparison of the velocity of compression waves (vp) for not reinforced and reinforced soil [41] 
laboratory pullout tests shows similar manner of mobilization of pullout resistance, so that the laboratory pullout test can be applied not only to explain the interaction mechanisms, but also to determine the design parameters [13]. Model pullout test gives conservative pullout resistance values compared to the field pullout in coherent soils [58]. Results of model and field pullout test presented in Figure 21 show similarities although geogrids with lower tensile strengths (Strata 500 and 750 UX) in field test show lower resistance values (expressed as interaction coefficient $\mathrm{Ci}$ ) than in laboratory tests and for stronger geogrids (UX 1500 and UX 1700) field pullout tests give higher resistance values [58].

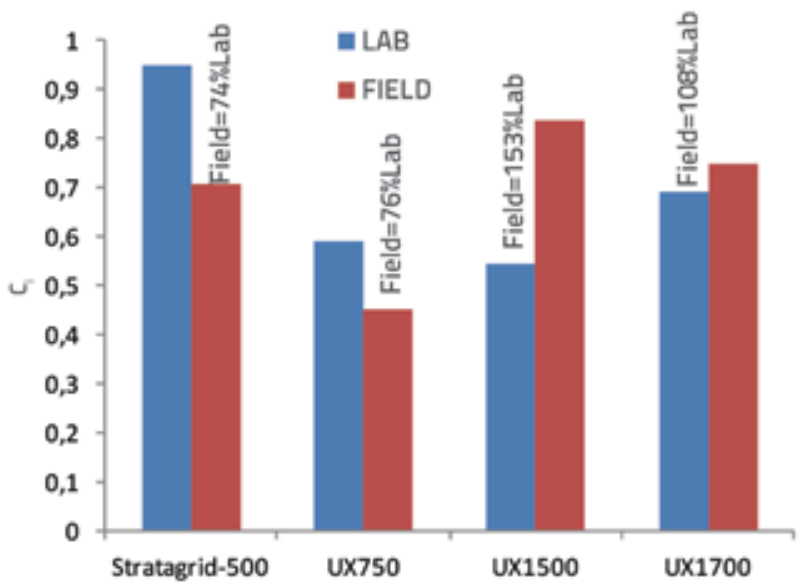

Figure 21. Comparison of interaction coefficients in model and field pullout test [58]

Model pullout tests are expensive and time-consuming and have restrictions related to the influence of boundary conditions and test methods on test results. Development of analytical and numerical methods for simulating the pullout test and forecasting the reinforcement (and soil) behaviour at pullout would avoid limitations of model test and reduce the need to carry out numerous pullout tests. In analytical methods, the reinforcement behaviour at pullout is described by development of forces and deformations in the reinforcement, but stresses and deformations, occurring in soil at reinforcement pullout using theese methods can not be determined. One of the most important method for estimating pullout force is Jewel's method [54] wherein the pullout force is calculated as follows:

$\mathrm{P}=\mathrm{P}_{\mathrm{tr}}+\mathrm{P}_{\text {pas }}$

A part of pullout force arising from friction is:

$\mathrm{P}_{\mathrm{tr}}=2 \cdot \mathrm{A}_{\mathrm{s}} \cdot \sigma_{\mathrm{n}} \cdot \tan \delta$

where:

$A_{s}$ - reinforcement surface under friction

$\sigma_{n}$ - normal stress

$\delta \quad$ - friction angle at contact of soil and reinforcement.
And force of soil passive resistance on grid transversal ribs:

$P_{p a s}=\left(L \cdot B \cdot t \cdot \alpha_{p} \cdot \sigma_{p}\right) / S$

where:

$L, B$ - dimensions of reinforcement sample

$\mathrm{t} \quad$ - transversal rib thickness

$\alpha_{p} \quad$ - the part of sample width responsible for mobilization of passive resistance

$\sigma_{p}$ - passive resistance mobilized on transversal ribs

$\mathrm{S}_{\mathrm{p}}$ - size of grid mesh.

Passive resistance $\sigma_{p}=\sigma_{n} \cdot N_{q}$ develops with general shear failure or modified punching failure which affects calculation of the bearing capacity coefficient $\mathrm{N}_{\mathrm{q}}$. One of the attempts to supplement equation (4) in order to adjust the calculated pullout resistance to the measured values was published by Moraci et al [33]. Jewel's solution gives good results in soils with smaller grain diameter (e.g. sand with grain diameters smaller than the thickness of the rib reinforcement) as shown by [12, 33, 54], but according to studies [3] it is not applicable for soil with larger grain diameter (e.g. coarse gravel). Using numerical models, with data on the length of the reinforcement activated at pullout, the height (thickness) of the soil zone around the reinforcement that participates in transmission of stress, or "reinforcement influence zone" can be determined. Numerical models were developed as 2D FEM models [35, 44, 46, 47, 60] and 3D FEM models [32], and their largest limitation is inability of modelling the actual behaviour of soil and grid reinforcement at pullout (for example, such models cannot include the impact of transversal ribs of geogrids and passive resistance, and load transfer from the reinforcement to soil is then modelled as friction). The problem is to determine properties of the reinforcement-soil contact that would adequately describe their interaction. An example of comparison of test results of pullout tests performed Perkins and Edens [47] and numerical 2D FEM model is shown in Figure 22.

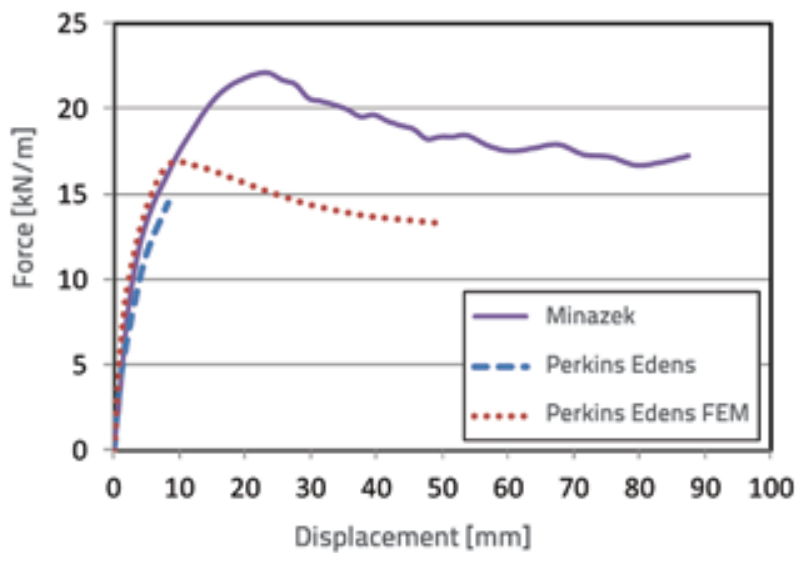

Figure 22. Comparison of model pullout test $[3,47]$ and FEM model [47] 
Numerical models developed so far were calibrated by selected model tests, while the forecast accuracy of behaviour is very limited for other materials and test conditions. At the moment there is no single solution that describes appropriately the soil and reinforcement interaction, which gives the parameters for structural design of reinforced soil. In order to eliminate restrictions resulting from the FEM model for the behaviour of reinforced soil, application of DEM models (DEM - discrete element method), for example, [61] began, where the soil particles are modelled as discrete elements, and in addition to surface roughness the reinforcement may have apertures as well as thickened nodes. At this moment there is few published results of analyzes using DEM models and stronger affirmation of this method is expected.

\subsection{Engineering parameters for design of the reinforced soil structures obtained by pullout test}

Given the very large number of types of geosynthetic reinforcement appearing on the market it is important to establish the criteria for selection of optimal reinforcement type and ways of reinforcement placement (length and spacing of reinforcement layers per height) in relation to the available fill type. The pullout test can help in making decisions in selection of the reinforcement type and in determination of the reinforcement length in reinforced soil structures. So far no general recommendations for selection of the reinforcement type have been prepared, so the test shall be carried out in each specific project.

Practical result of pullout test for engineering applications in the reinforced soil structures is expressed as the soil and reinforcement interaction coefficient $C_{i}$ that is used in determining the length of anchoring the reinforcement outside the sliding surface. Interaction coefficient Ci from equation (1) is defined as the ratio of shear strength at the contact of soil and reinforcement and soil shear strength. Knowing the soil friction angle (for non-cohessive soil, because it is commonly used as fill or omission of cohesion in the case of coherent soil, which benefits the safety [4]) in calculations of the reinforced soil structures $C_{i}$ is used to determine the required length of the reinforcement anchorage behind the assumed slip surface. This parameter describes the interaction of soil and reinforcement by friction, not taking into account other aspects of interaction. Its value is usually less than one (0.60.9 ), but in certain cases, such as with geogrids, can be higher than one, which suggests that the overall pullout resistance is higher than pure friction, and that other mechanisms (e.g. passive resistance to transversal ribs or interlocking effect) influence the increase of total pullout resistance. For preliminary calculations of the reinforced soil structures, geosynthetic manufacturers, based on their own studies, give the recommended values of interaction coefficients depending on the type of fill material. For example, Rimoldi et al [62] and Montanelli and Recalcati [63] provide the minimum and maximum values of the interaction coefficients at pullout for Tenax uniaxial geogrids, as shown in Table 2.

Table 2. Interaction coefficient $C_{i}$ for geogrid Tenax, under $[62,63]$

\begin{tabular}{|l|c|c|}
\hline \multicolumn{1}{|c|}{ Research } & $\begin{array}{c}\text { Rimoldi \& } \\
\text { others } \\
\text { (1994.) }\end{array}$ & $\begin{array}{c}\text { Montanelli \& Recalcati } \\
\text { (2003.) }\end{array}$ \\
\hline GRAVEL & $0.9-1.05$ & $0.90-1.50$ \\
\hline SAND & $0.75-0.95$ & $0.85-1.20$ \\
\hline DUST & $0.70-0.90$ & $0.75-1.00$ \\
\hline CLAY & $0.60-0.85$ & $0.70-0.90$ \\
\hline
\end{tabular}

In preliminary calculations for Fortrac $\mathrm{R}$ grid (knitted geogrids) the interaction coefficient value of 0.6 [64] is recommended as a conservative value in non-cohessive compacted soil. For Tensar RE and RE500 (extruded polypropylene uniaxial geogrids) testing by pullout test determined the value of $C_{i}>1.0$ where it is recommended to adopt $C_{i}=0.6$, [65]. For Miragrid XT (uniaxial) the preliminary calculations suggest the $C_{i}$ values from 0.9 to 1.0 for sand, $0.8-0.9$ for silt and $0.7-0.8$ for clay. [66].

There is no clear criterion that would define the manner of selection of vertical reinforcement spacing except that the total tensile force that is required to be taken over by the reinforcement is divided by the number of the reinforcement layers, taking into account the reinforcement tensile strength. It is usually estimated under "rule of thumb" and amounts to 0.3-0.6 $\mathrm{m}$ [67] regardless of the type of reinforcement and soil characteristics. In defining the vertical spacing of the reinforcement layers one should take into account the reinforcement influence height, where load transfer from the reinforcement to soil at pullout is occuring. It was studied by Minažek [3] in a model test and found that metal and the polymer biaxial in a natural gravel have the highest pullout resistance and the highest influence zone when the ratio of grid aperture size and the average grain diameter $S / D_{50}$ is approximately 2 , and influence zone height of the reinforcement is approximately $30 D_{50}$. It would be advisable to determine the influential reinforcement height for other cases of application of various types of reinforcements in different types of soil.

\section{Conclusion}

This paper describes the current knowledge on testing the soil and reinforcement interaction by pullout test, and achievements so far which are important for future studies and design practice are also discussed. The apparatus for reinforcement pullout from soil and methods of testing are 
not fully standardized, nor they are consistent with existing test standards. When selecting and planning pullout tests in research or practical engineering purposes, the authors recommend large pullout devices. In practice, it is important to carry out tests on fill and reinforcement materials that are planned to be installed in actual structures. All relevant studies show that geogrids, whose application in reinforced soil is dominant compared to other geosynthetic materials, are several times more efficient in soil reinforcement than geotextile, that the overall effects in reinforced soil depend on the geogrid type and soil characteristics and that differences in efficiency of particular geogrids are mostly noted in coarse grain soil. However, for the reason of simplicity, many previous studies with pullout test were performed using sand. As it was demonstrated that geogrids of different characteristics show similar pullout resistance at pulling out from sand because of the small grain diameter; $[48,55]$, and sand is not often used as fill, it can be concluded that studies should be conducted on coarse-grained materials dominating in actual application. Unfortunately, there are not many such studies.

In recent years, the importance of tensile strength of a geogrid is discussed mainly in cases where geogrids are used as ties, for example in reinforced embankments or reinforced soil walls, while the role of geogrid openings (apertures) is emphasized in soil reinforcement under the foundations or for the base courses of roads (recently called stabilisation).

There are several attempts to define the stiffness of reinforced composite by using geophysical methods [3, 38, 39, 68], but still with insufficient number of reliable results to recommend it as a valid and reliable method of identifying improvements of stiffness of reinforced soil.

There are no validated methods that would objectively determine "in situ" the contribution of the geogrid in reinforced soil to increase of its strength and capacity and reduce deformability. Nevertheless, it is encouraging to know that the reinforced soil with use of geogrids successfully solve challenging cases (embankments as high as up to 60 $\mathrm{m}$, improved load-bearing road layers, bearing platforms beneath embankments on soft soil, etc.) based on experiences, recommendations and specific (often manufacturer's) model tests on a large scale.

The soil and reinforcement interaction in reinforced soil is important for rational design of reinforced soil structures. Development of numerous geosynthetic products and application of increasingly broad range of soil fill materials in construction of reinforced soil results in growing requirements to clarify the mechanisms that explain the interaction between soil and reinforcement. Model tests of reinforced soil, especially by pullout test described in this paper, proved to be very useful in clarifying the interaction mechanisms of soil and reinforcement and enable determination of engineering parameters for design of reinforced soil structures. Model tests are useful because different versions of the soil-reinforcement relationship in reinforced soil can be explored simpler than in test polygons, which saves time and avoids costly and time-consuming "in situ" tests. Because of non-uniform research practice (not standardized tests and test procedures), it is difficult to compare the results of existing studies. It was found that testing in a large pullout device, with ensured minimizing the impact of boundary conditions, can give reliable results and information required in design of structures made of reinforced soil when it refers to the effect of geosynthetic reinforcement as a tie in soil. The pullout test is not sufficient to explain the interaction between geogrid and soil in increase of soil stability (roads, foundations). The practice expects answers to the following questions: (a) how to select the optimal geogrid for particular fill material in the reinforced soil structure, (b) what should be vertical spacing between geogrids, (c) how to make reinforced soil (for example, whether geogrid to be placed on the compacted layer or should it be placed in the half of non-compacted layer and then to compact soil), (d) how to determine mechanical properties of reinforced soil needed in calculation of deformation of the structure made of reinforced soil. Studies have shown that the anchorage zone of geogrids may be shorter than usual in practice, and that in cases of increasing stability of bearing layers (roads, foundations) only a small portion of the available tensile strength of geogrid is used. It should be expected that the results of recent scientific studies will stimulate development of new guidelines for design and construction of the reinforced soil structures, taking into account the effectiveness of geogrid used in selected soil.

In Croatia, studies of reinforced soil by pullout test at the Faculty of Civil Engineering in Osijek have been conducted for ten years. A large pullout device (called GFOS type), which, according to its properties (very large dimensions) belongs to a group of few devices that enable testing of actual fill materials with larger grain diameters is developed. It is characterised by innovative measurement capabilities (measurement of velocities of compression and shear waves, which determines the height of the geogrid influence zone). With additional improvements of measurement techniques it is expected to determine the potential of such innovative approach in studying the soil - reinforcement interaction in reinforced soil in combination with conventional pullout tests. 


\section{REFERENCES}

[1] Palmeira, E.M.: Soil-geosynthetic interaction: modeling and analysis (Mercer lecture 2007-2008), Proceedings of The 4th European Geosynthetics Conference, Edinburgh, (2008), pp. $1-30$

[2] Palmeira, E.M., Milligan, G.W.E.: Scale and other factors affecting the results of pull-out tests of grid buried in sand, Geotechnique 11 (1989) 3, pp. 511-524.

[3] Minažek, K.: Modelsko ispitivanje interakcije geomreže i tla doktorski rad, Sveučilište u Zagrebu, 2010.

[4] Koerner, R. M.: Designing with geosynthetics, Fifth edition, Pearson Prentice Hall, 2005.

[5] Juran, I., Knochenmus, G., Acar, Y.B., Arman, A. Pullout Response of Geotextiles and Geogrids (Synthetics of Available Experimental Data), Proceedings: Symposium on Geosynthetics for Soil Improvement, (1988), pp. 92-111,

[6] Farrag, K.: Pull-out testing facility for geosynthetics. LTRC PROJECT NO. 87-1GT, Lousiana Transportation Research Center, U.S. Department of Transportation, Federal Highway Administration, 1991.

[7] Moraci, N., Recalcati, P.: Factors affecting the pullout behaviour of extruded geogrids embedded in compacted granular soil, Geotextiles and Geomembranes, 24 (2006), pp. 220-242.

[8] Cuelho, E.V.: Determination of Geosynthetic Constitutive parameters and Soil/Geosynthetic Interaction by In-Air and InSoil Experiments, A thesis for the degree of Master of Science, Montana State University, 1998.

[9] ASTM D6706 - 01: Standard Test Method for Measuring Geosynthetic Pullout Resistance in Soil. ASTM International, 2007.

[10] Brand, S.R., Duffy, D.M.: Strength and Pullout Testing of Geogrids, Proceedings: Geosynthetic Conference, New Orleans Vol. 1, (1987), pp.226-236.

[11] Bauer, G.E., Halim, A., Shang, Q.: Large-Scale Pullout Tests: Assessment of Procedure and Results, Proceedings: Geosynthetics '91 Conference, Atlanta, (1991), pp. 615-627.

[12] Sieira, A.C.C.F: Experimental study on soil-geogrid interaction mechanisms, PhD. Thesis, Pontifical University of Rio de Janeiro, Brazil, 377 p, 2003.

[13] Ochiai, H., Otani, J., Hayashic, S., Hirai, T.: The Pull-Out Resistance of Geogrids in Reinforced Soil. Geotextiles and Geomembranes 14 (1996), pp. 19-42.

[14] Bergado, D.T., Chai, J.C.: Pullout Force/Displacement Relationship of Extensible Grid Reinforcements, Geotextiles and Geomembranes, Vol 13. (1994), pp. 295-316.

[15] Palmeira, E.M.: The study of soil-reinforcement interaction by means of large scale laboratory tests. PhD. Thesis, University of Oxford, UK, 1987.

[16] GRI Test Methods: GRI GG5 Geogrid Pullout, GRI, 1991.

[17] Technical Committee CEN/TC 189: EN 13738 Geotextiles and geotextile-related products - Determination of pullout resistance in soil. European committee for standardization, Technical Committee CEN/TC 189, Brussels, Belgium, 2004.

[18] Aydogmus, T., Klapperich, H.: Design and Evaluation of an Enhanced Shear and Pull-Out Testing Device, Proceedings of The 4th European Geosynthetics Conference, paper 170, 2008.

[19] Chang, J.C., Hannon, J.B., Forsyth, R.A.: Pullout resistance and interaction of earthwork reinforcement and soil. Transportation Research Record 640. National Research Council, Washigton, DC, (1977), pp. 1-7.
[20] Yuan, Z., Chua, K.M.: Numerical Evaluation of the Pullout Box Method for Studying Soil-Reinforcement Interaction. Transportation research record 1278, Transportation Research Board, Washington, D.C., (1991), pp. 116-124 .

[21] Marolo, C.A., Nirihiko, M., Bergado, D.T.: Soil Geogrid Reinforcement Interaction by Pullout and Direct Shear Tests. Geotechnical Testing Journal, Vol. 18, No. 2, June (1995), pp. 157167.

[22] Fannin, R.J., Raju, D.M.: On the pullout resistance of geosynthetics. Canadian Geotechnical Journal, Vol. 30, No. 3, (1993), pp. 409-417.

[23] Kharchafi, M., Dysli, M.: Study of Soil-Geotextile Interaction by an X-Ray Method. Geotextiles and Geomembranes, (1993), pp. 307-325.

[24] Min, Y., Leschinsky, D., Ling, H.J., Kaliakin, V.N.: Effects of Sustained and Repeated Tensile Loads on Geogrid Embedded in Sand, Geotehnical Testing Journal, Vol. 18, No. 2, (1995), pp. 204-225.

[25] Alfaro, M.C., Hayashi, S., Miura, N., Watanabe, K.: Pullout Interaction Mechanism of Geogrid Strip Reinforcement. Geosynthetics International, Vol. 2, No. 4, (1995), pp. 679-698.

[26] Lopes, M.L., Ladeira, M.: Role of specimen geometry, soil height and sleeve length on the pull-out behaviour of geogrids. Geosynthetics International 3 (6), (1996), pp. 701-719.

[27] Bernal, A., Salgado, R., Swan, R.H., Lovell, C.W.: Interaction Between Tire Shreds Ruber-Sand and Geosynthetics, Gesynthetics international, Vol. 4, No. 6, (1997), pp. 623-643

[28] Texeira, S.H.C.: Estudo da interacao solo-geogrelha em testes de arrancamento e a sua aplicacao na analise e dimensionamento de macicos reforcados. Tese apresentada a Escola de Engenharia de Sao Carlos, da Universidade de Sao Paulo, Sao Carlos,2003.

[29] Alagyawanna, A.M.N., Sugimoto, M., Sato, S., Toyota, H.: Influence of longitudinal and transverse members on geogrid pullout behaviour during deformation, Geotextiles and Geomembranes 19, (2001), pp. 483-507

[30] Bergado, D.T., Teerawattanasuk, C.: Analytical Models for Predicting the Pullout Capacyty and Interaction Between Hexagonal Wire Mesh and Silty Sand Backfill, Tamakang Journal of Science and Engineering, Vol. 4. No. 4, (2001), pp. 227-238

[31] Meyer, N., Nernheim, A., Emersleben, A.: Influence of confining pressure, soil density and types of geogrids on Soil-Geogrid interaction coefficientIntenational, e-Conference "Modern Trends in Foundation Engineering: Geotechnical Challenges and Solutions", IITM, India, 2003.

[32] Marques, J.M.M.C.: Finite element modelling of the pull-out test of geosynthetics. VIII International Conference on Computational Plasticity, Barcelona, 2005.

[33] Moraci, N., Gioffrè, D.: A simple method to evaluate the pullout resistance of extruded geogrids embedded in a compacted granular soil, Geotextiles and Geomembranes, 24(2), (2006), pp.116-128.

[34] Abdel-Rahman, A.H., Abdel-Moniem, I. M., Ashmawy, A.K.: Utilization of a Large-Scale Testing Apparatus in Investigating and Formulating the Soil Geogrid Interface Characteristics in Reinforced Soils, Australian Journal of Basic and Applied Sciences, 1 (2007) 4, pp. 415-430.

[35] Abdelouhab, A., Dias, D., Freitag, N.: Physical and analytical modelling of geosynthetic strip pull-out behaviour, Geotextiles and Geomembranes 28 (2010), pp. 44-53. 
[36] Bauer, G. E., Mowafy, Y. M.: The interaction mechanism of granular soils with geogrids, International Conference on Numerical Methods in Geomechanics 6, Innsbruck, (1988), pp.1263-1272.

[37] Lopes M.L., Lopes M.L. Soil-Geosynthetic Interaction - Influence of Soil Particle Size and Geosynthetic Structure, Gesynthetics international, Vol. 6, No. 4, (1999), pp. 261-282.

[38] Schuettpelz, C., Fratta, D., Edil, T. B,: Evaluation of the Zone of Influence and Stiffness Improvement from Geogrid Reinforcement in Granular Materials, Transportation Research Record: Journal of the Transportation Research Board, Report Numbers:09-2594, (2009), pp. 76-84.

[39] Tutumluer, E., Huang, H., and Bian, X. (2012). "Geogrid-Aggregate Interlock Mechanism Investigated through Aggregate ImagingBased Discrete Element Modeling Approach." Int. J. Geomech., 12(4), 391-398.

[40] Minažek, K., Kopić, Z., Mulabdić, M. Simple procedure of geogrid soil-interaction efficiency assesment, Tehnički vjesnik-Tehnical gazette. 19 (2012), 2; 399-405

[41] Mulabdić, M., Minažek, K.: Characterization of the Soil-grid Interaction by the Shear Wave Velocity. GIGSA GeoAfrica 2009 Conference, Cape Town, 2009.

[42] Giroud, J. P.: An assessment of the use of geogrids in unpaved roads and unpaved areas Proceedings of 2009 Geogrid Jubilee Symposium, 2009 Geogrid Jubilee Symposium, Institution of Civil Engineers, London, 2009.

[43] http://www.geofabrics.com.au/documents/Info-BulletinUnderstanding-Radial-stiffness.pdf, 15.1.2013.

[44] Sobhi, S. Wu, J.T.H.: An Interface Pullout Formula For Extensible Sheet Reinforcement, Geosynthetics International, Vol .3, (1996) 3, pp. 565-582.

[45] Mulabdić, M., Minažek, K., Cindrić, M.; Analiza pokusa izvlačenja geomreže iz nekoherentog tla, 4. savjetovanje HGD-a Ojačanje temeljnog tla i stijena, Opatija, (2006). pp. 233-240.

[46] Bergado, D.T., Teerawattanasuk, C.: Analytical Models for Predicting the Pullout Capacity and Interaction between Hexagonal Wire Mesh and Silty Sand Backfill, Tamakang Journal of Science and Engineering, Vol. 4. (2001) 4, pp. 227-238.

[47] Perkins, S.W., Edens M.Q.: Finite-element modelling of geosynthetic pullout test, Geotehnical and Geological Engineering 21, (2003), pp. 357-375.

[48] Mulabdić, M., Minažek. K.: Testing rib efficiency in geogrids, 9th International Conference on Geosynthetics, Garuja, (2010), pp. 743-746.

[49] Texeira, S.H.C.: Estudo da interacao solo-geogrelha em testes de arrancamento e a sua aplicacao na analise e dimensionamento de macicos reforcados, Tese apresentada a Escola de Engenharia de Sao Carlos, da Universidade de Sao Paulo, 2003.

[50] Yan, S., Bar, B.: FEM of soil-geogrid interaction with application to interpret the pull-out behavior of geogrid. Chinese Journal of Geotechnical Engineering, 19 (1997) 6, pp. 56-61.

[51] Santos, E.C.G.: The use of construction residues and recycled rubble in reinforced soil structures. MSc. Thesis, University of Sao Paulo, 2007.

[52] Zornberg, J.G., Mitchell, J.K.: Reinforced Soil Structures with Poorly Draining Backfills. Part I: Reinforcement Interactions and Functions, Geosynthetics International, Vol. 1(1994) 2, pp. 103148.
[53] Hossain, M.Z. and Sakai, T. A study on pullout behavior of reinforcement due to variation of water content of soil, Agricultural Engineering International: the CIGR Ejournal. Manuscript LW 07 011. Vol. IX. December, 2007.

[54] Jewell, R.A., Milligan, G.W.E., Sarsby, R.W., Dubois, D.D.: Interactions between soil and geogrids, Proceedings from the Symposium on Polymer Grid Reinforcement in Civil Engineering, London, (1985), pp. 18-30.

[55] Mulabdić, M., Minažek, K.: Nature of friction between geogrids and soil, Proceedings of the 5th European Geosynthetics Congress. Proceedings Vol 4. Topic 5: Soil improvement and reinforcement, Valencia (2012), pp. 435-440.

[56] Dyer, M.R.: Observation of the stress distribution in crushed glass with applications to soil reinforcement, PhD. Thesis, University of Oxford, UK., 1985.

[57] Becker, L.B.: Geogrid behaviour in reinforced soil walls and in pull-out tests, PhD. Thesis, Pontifical University of Rio de Janeiro, Rio de Janeiro, Brazil, 322 p. (in Portuguese),2006.

[58] Mohiuddin A.: Analysis of Laboratory and Field Pull-out Tests of Geosynthetics in Clayey soils, A Thesis Submitted to the Graduate Faculty of the Lousiana State University and Agricultural and Mechanical College in partial fulfillment of the requirements for the degree of Master of Science in Civil Engineering, B.E., Osmania University, 2001.

[59] Bergado, D.T., Lo, K.H., Chai, J.C., Shivashankar, R., Alfaro, M.C., Anderson, L.R.: Pullout tests using steel grid reinforcements with low-quality backfill, Journal of Geotechnical Engineering, ASCE USA Vol. 118, No. 7, (1992), pp. 1047-1063.

[60] Alfaro M.C., Hayashi S., Miura N., Watanabe K.: Pullout Interaction Mechanism of Geogrid Strip Reinforcement. Geosynthetics International, Vol. 2, No. 4 (1995), pp. 679-698.

[61] Aydogmus, T., Klapperich, H. Three-Dimensional Numerical Parametric Analysis of Soil-Geosynthetic-Interaction, EuroGeo4, Edinburgh, paper number 171.2008.

[62] Rimoldi, P., Ricciuti, A., Recalcati, P.: Tenax geosynthetics technical literature, Design manual: Steep reinforced slopes, Viganò, 1994.

[63] Montanelli, F., Recalcati, P.: Design Manual: The design of reinforced soil retaining walls using Tenax geogrids, Viganò, 2003.

[64] BBA technical approvals for construction, inspection, testing, certification: Agrément Certificate 05/4266, Fortrac R geogrids, Watford Herts, UK, 2008.

[65] BBA technical approvals for construction, inspection, testing, certification: Agrément Certificate 99/R109, Tensar RE and RE500 geogrids for reinforced soil retaining wall and Bridge abutment systems, Watford Herts, UK, 2010.

[66] http://www.tencate.com/amer/Images/tn_slopes_tcm299119.pdf, (1.10.2012.)

[67] German Geotehnical Society Recommendations for Design and Analysis of Earth Structures using Geosynthetic Reinforcements - EBGEO, Erns \&Sohn A Wiley Company, Berlin, 2011.

[68] Cox, B.R., McCartney, J.S., Curry, B., Wood, C.M, Young, C.: Insitu Strain Measurement during Dynamic Shear Loading of An Unbound Geogrid Reinforced Pavement Section, Proceedings Eighth International Conference on the Bearing Capacity of Roads, Railways, and Airfields, Champaign, Illinois, USA, 2009. 